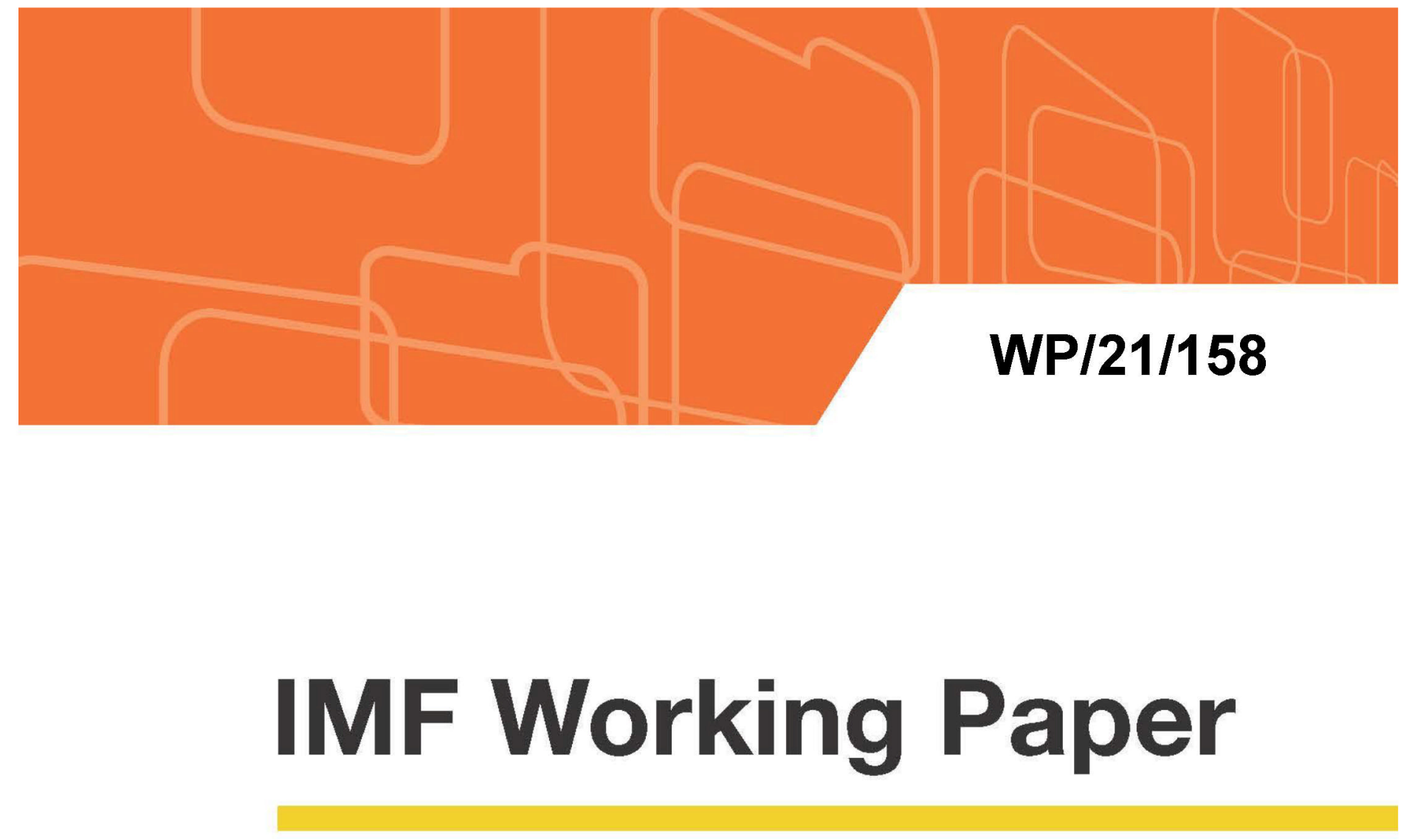

\title{
Are Passive Institutional Investors Engaged Monitors or Risk-Averse Owners? Both!
}

by Yuanchen Yang

IMF Working Papers describe research in progress by the author(s) and are published to elicit comments and to encourage debate. The views expressed in IMF Working Papers are those of the author(s) and do not necessarily represent the views of the IMF, its Executive Board, or IMF management. 


\title{
IMF Working Paper
}

Strategy Policy and Review Department

\section{Are Passive Institutional Investors Engaged Monitors or Risk-Averse Owners? Both! Prepared by Yuanchen Yang}

Authorized for distribution by Rupa Duttagupta

June 2021

\section{IMF Working Papers describe research in progress by the author(s) and are published to elicit comments and to encourage debate. The views expressed in IMF Working Papers are those of the author(s) and do not necessarily represent the views of the IMF, its Executive Board, or IMF management.}

\begin{abstract}
We differentiate the effects of passive institutional investors, which mainly refer to index funds that adopt a passive portfolio strategy, on firms' innovation activities and innovation strategies. Relying on plausibly exogenous variation in passive institutional ownership generated by Russell 1000/2000 index reconstitutions, we find that, with larger passive institutional ownership, while firms' countable innovation activities increase, they shift their innovation strategies by focusing more on exploitation of existing knowledge instead of exploring new technology. Enhanced monitoring by passive institutional investors through active votes could explain their positive effects on firms' innovation activities. Increasing risk aversion on the part of passive institutional investors appears the underlying force that drives firms' shift to incremental innovation. Our paper uncovers a subtle relation between institutional investors and innovation, which is largely ignored by earlier studies.
\end{abstract}

JEL Classification Numbers: G23; G30; O16; O31

Keywords: Passive Institutional Investors, Innovation, Exploitation, Exploration Author's E-Mail Address: YYang6@imf.org 
Abstract __ $\underline{2}$

I. Introduction $\underline{3}$

II. Institutional Background and Empirical Strategy ___ $\underline{6}$

A. The Russell Index__

B. Identification Strategy _

C. Empirical Framework __ $\underline{9}$

III. Data and Summary Statistics __ 10

A. Data Sources — 10

B. Variable Construction

C. Summary Statistics

IV. Main Findings _ 14

A. Discontinuities in Passive Institutional Ownership __ 14

B. Innovation Activity

C. Innovation Strategy __ 20

V. Plausible Underlying Channels ___ 24

A. Monitoring __ $\underline{25}$

B. Incentive _ 27

VI. Robustness Checks __ $\underline{32}$

A. Alternative Bandwidths _ 32

B. Alternative Polynomial Orders

C. Alternative Russell Rankings___ 37

D. Alternative Institutional Ownership Definitions __ 37

E. Placebo Thresholds _ 37

VII. Conclusion__ $\underline{38}$

References _ _ $\underline{39}$

Appendix__ $\underline{43}$ 


\section{INTRODUCTION}

One of the most important trends in corporate governance and asset investment in the past decade has been the rise of passive institutional ownership. Passive institutional investors mainly refer to index funds that adopt a passive portfolio strategy, seeking to maximize returns by replicating and holding a representative benchmark. The dramatic increase in corporate ownership by passive investors triggers growing concerns over its effect on market efficiency (BIS, 2018) and financial stability (IMF, 2019). ${ }^{1}$ It also raises important issues for agency problems in firms because it is uncertain to what extent passive funds have incentives and capacity to monitor their diverse portfolios, and ultimately, to shape portfolio companies' policies (Blanding, 2017). Hence, in this paper, we examine the effect of passive institutional investors on portfolio firms' performance. In particular, we focus on the firms' technological innovation, which is the fundamental force that shapes firm dynamics (Porter, 1985) and aggregate productivity and economic growth (Solow, 1957).

Holmstrom (1989) points out that agency costs associated with innovation are especially high as innovative projects are long-term, highly risky, and unpredictable in terms of outcome. Motivating innovation is, therefore, a challenge for most firms (Manso, 2011). Institutional investors should have an advantage, because they are sophisticated investors and repeated market players, which lowers the coordination cost and increases returns to monitoring (see, for example, Shleifer and Vishny, 1986; Kahn and Winton, 1998). A growing body of evidence suggests that passive institutional investors are actually active monitors of the firms in which they hold stakes, helped by proxy advisory services, such as ISS or Glass-Lewis, to shape corporate policies (e.g., Fich, Harford, and Tran, 2015; Fisch, Hamdani, and Solomon, 2019) and vote on innovation strategies. ${ }^{2}$ Higher levels of monitoring mitigate information asymmetry, increase work effort, and push managers to act in the best interest of shareholders (Jensen and Meckling, 1976; Harris and Raviv, 1978). Thus, firms more heavily monitored by institutional investors are expected to deliver better innovation performance.

However, institutional investors may be averse to risks as their fiduciary duty as fund managers pushes them to choose less risky projects (Sias, 1996; Del Guercio, 1996). As a result, institutional investors may exhibit preferences for near-term, certain earnings over long-term, uncertain returns, and pressure managers into myopic investment behavior, such as reducing research and development $(R \& D)$ expenses that could take years to yield profits. Risk-aversion on the part of institutional investors breeds managerial risk-aversion, arousing doubts about whether managers would be incentivized to invest in risky and novel innovation, which may be value-enhancing in the long term or may fail completely (Benartzi and Thaler, 1995; Holmstrom, 1999; Manso, 2011; Tian and Wang, 2014).

In short, there is little, if any, conclusive evidence as to whether passive institutional investors stimulate or suppress innovation because the question is more subtle than it appears and needs careful examination. We answer this research question by differentiating the effect

\footnotetext{
${ }^{1}$ BIS Quarterly Review, 2018. The Implications of Passive Investing for Securities Markets, March 2018; International Monetary Fund, 2019. Global Financial Stability Report, April 2019.

${ }^{2}$ Financial Times, 2018. Fund Managers Turn to Innovation to Beat Glum Forecasts, August 29.
} 
of passive institutional investors on innovation activities and innovation strategies. A firm's innovation activity includes its observable, countable innovation input and output, such as R\&D expenses, patent counts, and patent citations. A firm's innovation strategy, however, is more complicated and subtle, which is not as straightforward as innovation activities. It could reflect the scope, breadth, depth, and fundamental nature of the firm's innovation effort. Hence, passive institutional investors could have different effects on a firm's innovation activity and strategy.

A standard approach that assesses the effects of passive institutional investors is to undertake the ordinary least squares (OLS) regressions that regress a firm's innovation activity and strategy on the firm's passive institutional ownership and control variables. This approach, however, suffers from two main identification difficulties. First, passive institutional ownership and the firm's innovation activity and strategy could be driven by common characteristics that may not be observable to econometricians, which causes the omitted variable concern. Second, expected changes in a firm's innovation activity and strategy could attract passive institutional investors. This is the typical reverse-causality concern. Hence, the results obtained from a standard OLS estimation may tell us little about the causal effect of passive institutional investors on a firm's innovation activity and strategy.

To tackle the identification difficulties, we use plausibly exogenous variation in passive institutional ownership generated by annual Russell index reconstitutions to establish the causality between passive institutional ownership and innovation activity and strategy. Firms are assigned to Russell 1000/2000 indices solely based on their market capitalizations on the last trading day in each May, forcing index-tracking funds to buy or sell their stocks. This feature breaks the link between firm and owner characteristics, and thereby provides us with a clean identification of the causal effect of passive institutional ownership on firm innovation activity and strategy. Due to the value-weighted nature of each index, firms just included in the top of the Russell 2000 index have discontinuously higher institutional ownership than firms in the bottom of the Russell 1000 index. Conducting analyses on firms near the Russell index threshold enables us to compare the differences in innovation activity and strategy driven entirely by varying levels of passive institutional ownership. We discuss more institutional details on Russell index reconstitutions in Section 2.

Using R\&D expenditures, patent counts, and patent citations, which are well-established measures of innovation input and output (He and Tian, 2018; 2020), to capture a firm's innovation activity, we document a significant increase in a firm's innovation input (R\&D expenditures) and output (patent counts and citation counts) after an exogenous increase in institutional ownership. The results are robust to using alternative measures of institutional ownership, alternative bandwidths, alternative kernels, and various placebo tests.

A firm's innovation strategy, however, is more complex than what is reflected in the simple measures of patent and citation counts. We complement patent-based metrics of innovation activity with indicators that distinguish between innovative exploitation and exploration. The first indicator is the number and length of patent claims: If a firm is exploring a new technology that promises to make a broad contribution to the field, the patent should have fewer claims and the claims should be relatively shorter, as a reflection of the broader scope. 
We find that both the number and the length of patent claims increase after an increase in passive institutional ownership, suggesting that firms are increasingly engaged in incremental research and make marginal contributions to already crowded fields. Second, we find that citations made to the patents filed by firms with an increase in passive institutional ownership tend to fall into the middle of the citation distribution, along with a thinning of the tails. In other words, passive institutions have an insignificant effect on uncited and highly cited patents, which reflects a firm's effort on breakthrough innovation, but a significantly positive effect on incremental innovations that receive a moderate number of citations. Third, our findings indicate that despite the significant increase in patent and citation counts, the number of patents that are filed in new areas - the fields in which a firm has not patented before-does not change significantly. Finally, both originality and generality of patents shrink and fewer of patents are turned into new products after a firm's passive institutional ownership increases. Thus, with higher levels of passive institutional ownership, firms' innovation strategies tend to focus more on the exploitation of current knowledge rather than the exploration into new fields.

After establishing a causal link between passive institutional ownership and a firm's innovation activity and strategy, we try to explore plausible underlying economic channels. First, we postulate and test a monitoring channel. Due to the long-term and high-risk nature of technological innovation, managers have incentives to shirk, i.e., "enjoy the quiet life", and stay away from innovation activities. Intensified monitoring by institutional investors leads to increased effort of managers and hence increases a firm's innovation input and output. We term this argument the monitoring channel. By tracking the voting behavior of passive funds, we find that firms whose passive ownership increases due to index reconstitutions are likely to be more intensively monitored. Passive institutional investors not only participate actively in shareholder meetings but also vote favorably to management. With greater oversight from institutional investors, managers are forced to expend more effort on innovation activities, which results in more observable innovation input (R\&D expenditures) and output (patent counts and citation counts).

Next, we hypothesize that passive institutional investors, despite increasing a firm's observable and countable innovation input and output, could induce the firm to focus more on exploitation as opposed to exploration because of increasing risk aversion. They could do so by altering managers' incentive schemes. We term this argument the incentive channel. We find that an exogenous increase in passive institutional ownership leads to a higher probability of forced CEO turnover in case of poor financial performance or adverse market response. Meanwhile, the Vega of executive compensation, which measures managers' risktaking incentives, does not increase with more passive institutional ownership. Moreover, we find that institutional investors reduce CEO power by increasing board independence and reducing severance pay. By contrast, previous research shows a positive relation between CEO power and explorative innovation (Sariol and Abebe, 2017). Taken together, passive institutions do not appear to offer incentives for risky exploration, which involves a high probability of failure and hence potentially unsatisfactory short-term performance. Under greater career concerns, managers are more likely to avoid taking risks and to engage in exploitation that offers quicker and more certain returns. 
This paper contributes to two strands of literature. First, it adds to the fast-going literature on institutional investors and corporate innovation. Aghion et al. (2013) find an overall positive association between institutional ownership and innovation outcomes. They argue that the results are consistent with the career concern channel in which institutions help insulate managers from reputation damages in case the risky innovation leads to bad outcomes. Luong et al. (2017) find a positive, causal effect of foreign institutional ownership on corporate innovation, which can be explained by better monitoring, more insurance, and more knowledge spillovers. Brav et al. (2018) focus on the role played by hedge funds. They find that firms targeted by hedge fund activists are able to enhance their innovation efficiency and the main underlying channels are the reallocation of innovative resources and the redeployment of human capital. Different from earlier studies that either do not distinguish the type of institutional investors or focus solely on active institutional investors, our paper focuses on passive institutional investors and pushes this line of inquiry further by differentiating the effects of passive institutional investors on innovation activities and innovation strategies. ${ }^{3}$

Second, our paper contributes to the literature on passive institutional ownership. Existing studies show that passive institutional investors play various active roles, such as sharpening CEO incentives (Mullins, 2014), improving firm transparency (Boone and White, 2015), enhancing corporate governance (Appel et al., 2016), and leading to favorable acquisition outcomes (Fich, Harford, and Tran, 2015) and higher payouts (Crane et al., 2016). However, there is little, if any, insight into the effect of passive funds on a firm's innovation activity and strategy. This study is the first attempt to reveal the role of passive institutional investors in shaping firms' innovation activities and strategies. ${ }^{4}$

The remainder of the paper is organized as follows: Section 2 provides institutional background and discusses our empirical strategy. Section 3 describes our data. Section 4 reports the main results. Section 5 explores plausible underlying channels. Section 6 reports robustness checks and Section 7 concludes.

\section{INSTITUTIONAL BACKGROUND AND EMPIRICAL STRATEGY}

\section{A. The Russell Index}

The Russell index series is developed by the FTSE Russell. Stocks of the 3,000 largest companies listed in the United States make up the market-value-weighted Russell 3000

\footnotetext{
${ }^{3}$ Other studies that explore finance and innovation include Acharya et al. (2013), Bradley et al. (2017), Chemmanur et al. (2014), Cornaggia et al. (2015), Fang et al. (2014), Gu et al. (2017), He and Tian (2013), Hirshleifer et al. (2012; 2018), Hsu et al. (2014), Lerner et al. (2011), Levine, Lin, and Wei (2017), Lin, Liu, and Manso (2019), Manso (2011), Moshirian et al. (2020), Seru (2014), and Tian and Wang (2014). See, e.g., He and Tian $(2018 ; 2020)$ for surveys of this literature.

${ }^{4}$ A contemporaneous study by Liu et al. (2020) examines a similar research question as ours. They find that great passive institutional ownership leads to increases in R\&D expenditures, patent counts, and patent citations. Our paper differs from theirs by pushing this line of inquiry further and discovering the roles played by passive institutional investors in altering firms' innovation strategies of shifting from breakthrough to incremental innovation.
} 
Index. The top 1,000 of those companies constitute the large-cap Russell 1000 Index, whereas the bottom 2,000 companies comprise the small-cap Russell 2000 Index.

The construction of the Russell 1000 and 2000 indices, which are of particular interest for our study, is based on firms' market capitalization on the last trading day in May in each year. After the market closes on that day, Russell ranks all firms according to their proprietary measure of market capitalization and this alone determines firms' index membership. Although the market capitalization measure and the exact end-of-May rankings are not publicly available, Russell does disclose the methodology of calculating the market capitalization that generates the ranking of index constituents. First, Russell only considers firms headquartered in the United States with stock price at or above \$1. It then obtains the firms' stock price and total number of common shares outstanding from the FT Interactive data. It also relies on the SEC and other sources in case of missing or questionable information. Market capitalization is computed by multiplying the closing share price by the total number of all common shares outstanding, excluding preferred stock and stock not held to be freely floating. In the event of multiple share classes, Russell uses the market capitalization implied by the share price of the "primary trading vehicle", as defined by a unique Russell algorithm.

Index assignments take place at the end of each May, but index weights are determined at the end of each June. These assignments and weights will then be made available to the public and persist until the next June. Index weights are computed based on float-adjusted market capitalization at the end of June, the data of which are again considered proprietary by Russell. This adjustment, along with the return in June, could change the ranking of firms relative to the threshold decision made in May. For instance, if two firms are ranked the $1000^{\text {th }}$ and $1001^{\text {st }}$ by market capitalization at the end of May, those firms will be assigned to the Russell 1000 and 2000 indices, respectively. However, the two firms may not necessarily be the lowest and highest weighted firms in their respective indices in June. Thus, there is a difference between the market capitalization used for index assignment and the market capitalization used to determine index weights. It should be noted that such adjustment does not reassign firms to a different index; it only affects the index weights after the index constituents have been determined.

\section{B. Identification Strategy}

Our identification strategy makes use of plausibly exogenous differences in passive institutional ownership between the highest weighted firms in the Russell 2000 index and the lowest weighted firms in Russell 1000. If a firm is ranked the $1001^{\text {st }}$ in May of year $t-1$ and then ranked the $1000^{\text {th }}$ in May of year $t$, it will switch indices from Russell 2000 to Russell 1000 in year $t$. Institutions that passively track the Russell 2000 index are then obliged to sell the stock of the firm, and to buy the stock that replaces it.

There are good economic reasons to believe this difference to be significant. On the one hand, firms at the top of Russell 2000 have large index weights while firms at the bottom of

Russell 1000 have merely trivial weights. Therefore, funds tracking Russell 1000 could hold none of the firms at the bottom of the index with hardly any impact on their performance, whereas firms at the top of the Russell 2000 index are likely to be held by any fund tracking 
Russell 2000 in order to keep the tracking error to a minimum (Roll, 1992). On the other hand, the Russell 2000 index is the most popular Russell index with regard to assets benchmarked, which means that more funds are benchmarked to Russell 2000 than Russell 1000. Russell 1000 has to compete with S\&P 500 for large-cap stocks, whereas Russell 2000 faces little competition within the small and mid-cap realm. According to Morningstar, the amount of assets benchmarked to the Russell 2000 index exceeded \$1.2 trillion in 2018 while only $\$ 500$ billion tracked Russell 1000 in the same period.

The combination of relative index weights and total benchmarked assets suggests that institutional investors hold a greater share of firms at the top of Russell 2000 compared to those at the bottom of Russell 1000 and that this difference is not a function of firm characteristics, but rather the composition of the index. Therefore, the Russell index reconstitution helps to address the concern of endogeneity in institutional ownership by creating plausibly exogenous variation in passive institutional ownership.

One important challenge to our identification is that Russell keeps its end-of-May market capitalization proprietary and makes float adjustments to the index composition at the end of June. Therefore, we need to reconstruct the end-of-May ranking that Russell uses to determine index membership to make sure that the assignment to Russell 1000/2000 is solely based on market capitalization and is locally random at the threshold.

To do this, we first take all 3,000 firms in the Russell 3000 universe and restore the end-ofMay market capitalization within the actual assigned index based on publicly available data. We obtain the end-of-May share price information from CRSP and the number of shares outstanding measured by quarterly shares outstanding item from Compustat. We use Compustat quarterly earnings report date to determine the fiscal quarter that is closest to the last trading day of May, and then use monthly CRSP factor to adjust the share item to account for any corporate distribution after the fiscal quarter-end and before the end of May. For any missing price or share information, we extract the data manually from Bloomberg. Finally, we choose the larger of the shares obtained from this procedure and the CRSP shares when defining the number of shares outstanding.

We then perform the McCrary (2008) test to ensure local randomness, i.e., firms close to the Russell 1000/2000 index threshold do not have precise control over which side of the threshold they end up on. Since the distribution of market capitalization shifts up every year in our sample, we examine the density of the underlying assignment variable: Russell market capitalization on an annual basis. Average annual $t$ statistics for the McCrary test of discontinuity in the density of market capitalization for a bandwidth of 300 firms is 0.44 , which is not statistically significantly different from zero. Hence, we are unable to reject the null hypothesis that the forcing variable exhibits continuity of the density function at the threshold, suggesting that firms cannot precisely manipulate their market capitalization to be put on a specific side of the index cutoff.

After 2006, however, Russell implemented a so-called "banding" policy to maintain consistency in the respective indices. A stock will remain in its original index if its market capitalization does not deviate far enough to warrant an index change. As the Russell index 
assignment is no longer based exclusively on market capitalization, we drop all observations after 2006 when Russell instituted this banding policy to avoid introducing noise to our quasi-natural experiment.

\section{Empirical Framework}

We show in the previous subsection that the Russell index assignment is solely a function of market capitalization. Firms just to the left and just to the right of the index cutoff are comparable in potential outcomes, except for having landed on opposite sides because of small differences in their market capitalization at the end of May. Although differences in market capitalization around the cutoff are small, they generate a large gap in institutional ownership due to the index tracking behavior by passive institutions. Therefore, our identifying assumptions of the regression discontinuity design are satisfied and we can use Russell 2000 index membership around the cutoff as the instrument for passive institutional ownership.

To examine the effect of passive institutional ownership on a firm's innovation activity and strategy, we estimate the model below, following earlier research (e.g., Boone and White, 2015):

$$
\begin{gathered}
P_{I O}=\alpha+\tau R 2000_{i, t}+f\left(R_{i, t}\right)+\gamma F_{i, t}+\delta X_{i, t-1}+u_{i}+v_{t}+\epsilon_{i, t} \\
Y_{i, t+n}=\beta_{0}+\beta_{1} \widehat{P I O_{l, t}}+g\left(R_{i, t}\right)+\beta_{2} F_{i, t}+\beta_{3} X_{i, t-1}+u_{i}+v_{t}+\xi_{i, t}
\end{gathered}
$$

where $i$ indexes firm and $t$ indexes time. The first stage regression can be thought of as a sharp regression discontinuity design in which $R 2000_{i, t}$ is a dummy variable that equals one if firm $i$ is placed in the Russell 2000 index in year $t$, and zero otherwise. $R_{i, t}$ signifies the market capitalization rank of firm $i$ in year $t$ minus 1,000, and it is determined by the end-ofMay market capitalization. $F_{i, t}$ represents the proxy for Russell index float adjustment, computed as the difference between the end-of-May market capitalization rank and the actual rank assigned by the FTSE Russell in June. $P I O_{i, t}$ refers to the passive institutional ownership of firm $i$ in the next available quarter after the index reconstitution in year $t$.

In the second stage regression, we estimate the effect of instrumented $P I O$ on $Y_{i, t+n}$, a battery of innovation activity and strategy measures (R\&D, patents, citations, the number and length of patent claims, originality and generality scores, etc.) in the $n$-th year after the index reconstitution, and $n$ equals 1,2 , or $3 . X_{i, t-1}$ is a vector of time-varying firm characteristics used as controls and lagged by one year. $u_{i}$ symbolizes firm fixed effects, which captures unobserved heterogeneity at the firm level, and $v_{t}$ represents year fixed effects, which mitigates concerns that the results are driven by secular changes. The function $f$ (and likewise for $g$ ) is parameterized as a $\kappa$-th order polynomial to allow the relation between $R_{i, t}$ and $P I O_{i, t}$ $\left(Y_{i, t+n}\right.$ for $g$ ) to vary depending on the distance to the index threshold on either side. By including functions $f$ and $g$, we control for the functional form of the market capitalization rank and isolate any discontinuity around the threshold. Specifically, $f$ takes the following form:

$$
\sum_{j=1}^{k} \eta_{j} R_{i, t}^{j}+\sum_{j=1}^{k} \theta_{j} R 2000_{i, t} R_{i, t}^{j}
$$


To account for potential within-firm dependence over time, we cluster standard errors by firm.

\section{Data AND Summary STATISTICS}

\section{A. Data Sources}

We collect data from a variety of sources. Russell index constituent information is provided by the FTSE Russell. We obtain institutional ownership data from the SEC 13F filings in the Thomson Reuters Institutional Holdings database, and identify passive institutions using Bushee's (2001) classifications. We construct various innovation measures based on the NBER Patent Citation database and the United States Patent and Trademark Office (USPTO) Bulk Data Storage System (BDSS). New product releases are compiled from the Key Developments database in Capital IQ. Shareholder voting information and board independence data are obtained from the Institutional Shareholder Services (ISS)/RiskMetrics database. We gather CEO turnover and compensation data from the Execucomp database. We also include a battery of controls that can affect a firm's innovativeness following the prior literature.

\section{B. Variable Construction}

The FTSE Russell provides us with the Russell 1000 and Russell 2000 index composition data since 1984, the year when the indices were first launched. In addition to annual index constituents, the data also includes index weights and market capitalizations on the day of each reconstitution.

We match the institutional ownership data extracted from Thomson Reuters Institutional Holdings (13F) to Quarterly CRSP/Compustat Merged data to obtain the total number of common shares outstanding at the firm level. We then use Bushee's (2001) permanent classification of fund managers as (i) "quasi-indexers" (low turnover, high diversification), (ii) "transient investors" (high turnover, high diversification) and (iii) "dedicated investors" (low turnover, low diversification) to categorize institutional investors. ${ }^{5}$ To identify passive institutions, we create an indicator that equals one if the fund manager is classified as a "quasi-indexer" and zero otherwise. While this is a noisy identifier of passive institutions, it does capture all the large index funds that track Russell 1000 and 2000 indices, such as Blackrock and Vanguard. We merge this identifier to the institutional ownership data and match the merged dataset to the Russell data.

Finally, we calculate institutional ownership $(I O)$ as the proportion of institutional holdings to the total number of common shares outstanding of a stock. Passive institutional ownership $(P I O)$ is defined as the percentage of quasi-indexers in total shares outstanding.

To construct innovation variables, we first use firms' research and development $(R \& D)$ expenditures as a measure of innovation input. Most of the recent empirical research has relied on patent and citation data to capture firm-level innovation output (see, e.g., He and

\footnotetext{
${ }^{5}$ Bushee's (2001) classification data are available at http://acct.wharton.upenn.edu/faculty/bushee/IIclass.html.
} 
Tian, 2018; 2020 for surveys). To be comparable with the previous literature, we use patent and citation counts as measures of innovation output and obtain the data from the NBER patent database that contains information on patent assignee, patent counts, patent citations, and a patent's application and grant year, etc. starting from 1976. We define patent count as the total number of patents applied (and eventually granted) by a firm in a year. Citation count refers to the total number of forward citations received by a firm scaled by the number of its patents. Given that these measures are highly skewed, we use the logarithm of one plus the number of patents (LnPat) or citations (LnCite) in the regressions, following the previous studies.

While patent and citation counts, to some extent, reflect the technological novelty and commercial value of firms' innovation activities (Hall et al., 2005), they are crude measures and have limited abilities to help understand firms' innovation strategies (Argente et al., 2019). Inspired by Lanjouw and Schankerman (2004), we construct multiple alternative innovation measures, mainly based on the USPTO BDSS database, to allow the illustration of a more detailed and complete picture of how passive institutions affect not only the quantity and quality but also the fundamental value and nature of firm innovation. More specifically, these measures include the scope of patent claims, the distribution of citations, the technological trajectory of patents, and the introduction of new products, etc.

First, we examine patent claims. In a patent application, claims delineate the intellectual property rights protected by the patent and define the scope of the invention. Patent full texts are parsed at the claim level and then aggregated into patent-level statistics, such as claim number (ClaimNo) and claim length (ClaimLength). Claim number is defined as the average number of claims of all patents filed by a firm in a year, and claim length measures the average word count in a firm's patent claims.

Next, we classify patents according to the number of citations that they receive relative to other patents granted in the same technology class in a year. If a patent is located in the top 10 percent of the citation distribution, it is labeled as an impactful breakthrough. If a patent receives no citation, it is labeled as a failed invention. The rest are labelled as incremental innovations.

Another way to investigate whether a firm is undertaking incremental research or pushing forward knowledge boundaries is by investigating whether it files patents in new technology classes or not. For all the firms in the chosen bandwidths which have patent filings in a year, we count the number of patents that belong to the technology classes in which a firm has never filed patent applications before and term it as NewField.

We also examine patent originality and generality. The two indicators are first developed by Trajtenberg et al. (1997) and are readily available in the NBER patent database. Patent originality refers to the breadth of the technology fields on which a patent relies. Following Hall et al. (2001), we compute it as

$$
\text { Originality }_{i}=1-\sum_{j}^{n_{i}} s_{i j}^{2}
$$


where $s_{i j}$ stands for the percentage of citations made by patent $i$ to patent class $j$ out of $n_{i}$ patent classes. Conversely, patent generality measures the range of technology fields that cite a patent. Similar to the originality indicator, it is defined as

$$
\text { Generality }_{k}=1-\sum_{l}^{n_{k}} s_{k l}^{2}
$$

where $s_{k l}$ denotes the percentage of citations received by patent $k$ that belong to patent class $l$, out of $n_{k}$ patent classes.

Finally, we supplement the set of patent and citation measures with new product information to evaluate how patent-based metrics of innovation relate to actual product introduction. New product announcements are hand collected from the Capital IQ database that contains company press releases. Due to data limitations, new product information starts from 1995.

Following the existing innovation literature, we control for a set of variables that could affect a firm's innovation performance, including firm size $(\ln ($ Assets $))$, firm age $(\ln ($ Age $))$, investment in intangible assets $(R \& D)$, capital expenditures (Capex), asset tangibility (PPE), leverage (Lev), profitability $(R O A)$, industry concentration $(H H I)$, financial constraints $(K Z$, Kaplan and Zingales, 1997), and growth opportunities (Tobin's Q). We also control for firm and year fixed effects. All variables are winsorized at the top and bottom 1 percent percentiles to minimize the influence of outliers.

\section{Summary Statistics}

Our sample period starts from 1984 and ends in 2006, because the Russell index composition data are available only from 1984. The local randomization assumption underpinning the regression discontinuity design generally requires a narrow bandwidth: as one moves away from the cutoff, it becomes increasingly less likely that the firms on either side are similar ex ante. With a narrow bandwidth, the functional form becomes much less of a concern and treatment effects can be estimated with parametric regression using a linear or piecewise linear specification of the forcing variable (Lee and Lemieux, 2010). Yet as Schochet (2008) points out, a narrower bandwidth could result in less precise estimates if the outcome-score relation can be correctly modeled using a wider range of scores. A viable alternative is to use a wider bandwidth and to control for increasing heterogeneity across the boundary with a flexible polynomial function. Balancing the tradeoff between more statistical power and lower biases, we choose a bandwidth of 300 firms on either side of the index cutoff, and end up with a sample of 7,035 firm-year observations in total. Later in the robustness section, we show that our estimates are robust to alternative bandwidths as well as the algorithm-selected optimal bandwidth obtained based on Imbens and Kalyanaraman (2012). Table 1 presents the summary statistics. 


\section{Table 1. Summary Statistics}

Table 1 provides firm-year level summary statistics of key variables of interest in this study. Variable definitions are provided in the Appendix.

\begin{tabular}{|lcccc|}
\hline Variable & $\mathrm{N}$ & Mean & Median & StDev \\
\hline LnPat & 7,035 & 0.732 & 0.000 & 1.199 \\
LnCite & 7,035 & 0.883 & 0.000 & 1.346 \\
ClaimNo & 7,035 & 0.984 & 0.000 & 1.379 \\
ClaimLength & 7,035 & 1.445 & 0.000 & 1.982 \\
Breakthrough & 2,463 & 0.685 & 0.693 & 0.836 \\
Incremental & 2,463 & 1.828 & 1.609 & 1.087 \\
Failure & 2,463 & 0.388 & 0.000 & 0.733 \\
NewField & 2,463 & 1.906 & 1.792 & 1.203 \\
Originality & 2,085 & 0.533 & 0.559 & 0.232 \\
Generality & 1,896 & 0.549 & 0.580 & 0.243 \\
Product & 3,808 & 0.016 & 0.000 & 0.110 \\
IO & 7,035 & 0.505 & 0.536 & 0.293 \\
PIO & 7,035 & 0.320 & 0.330 & 0.197 \\
TIO & 7,035 & 0.136 & 0.110 & 0.117 \\
DIO & 7,035 & 0.033 & 0.010 & 0.058 \\
LnAssets & 7,035 & 6.342 & 6.326 & 1.132 \\
LnAge & 7,035 & 3.131 & 3.219 & 0.727 \\
R\&D & 7,035 & 0.030 & 0.000 & 0.064 \\
Capex & 7,035 & 0.075 & 0.056 & 0.074 \\
PPE & 7,035 & 0.556 & 0.486 & 0.378 \\
Lev & 7,035 & 0.460 & 0.464 & 0.206 \\
ROA & 7,035 & 0.155 & 0.149 & 0.108 \\
HHI & 7,035 & -5.738 & 1.58 & \\
KZ & 7,035 & & & \\
TobinsQ & & & 0.686 \\
\hline
\end{tabular}

On average, a firm applies for and is eventually granted 5.7 patents a year, and each of its patents receives 7.3 forward citations. An average patent has 6.1 claims and each claim has 22.6 words. The fact that the mean value of patent and citation counts is larger than the median value suggests a highly skewed distribution of innovation activities in the sample, with patents and citations mainly concentrated in most productive firms. Approximately 35 percent (2463) of the firms in the final sample have applied for and been eventually granted at least one patent. For these firms, on average, 14.1 patents are filed in new technology 
classes. 2.2 patents fall into the top 10 percent category; 1.4 patents are never cited; and 11.3 appear in the middle of the citation distribution. Mean scores for patent originality and generality are 0.53 and 0.55 , respectively. Furthermore, the average number of new products introduced is 0.02 .

For institutional ownership, an average firm has an ownership base composed of 50.5 percent institutional investors, among which 6.5 percent are dedicated institutions, 26.9 percent are transient investors, and 63.4 percent are quasi-indexers, or passive institutional investors by our definition.

In terms of other firm characteristics, the typical firm in the sample has been listed for 29.1 years, with a book value of assets of $\$ 1.1$ billion, an R\&D to asset ratio of 3.0 percent, a capital expenditure to asset ratio of 7.5 percent, a PPE to asset ratio of 55.6 percent, a leverage ratio of 46.0 percent, a return on assets ratio of 15.5 percent, a $\mathrm{KZ}$ index of -5.7 , and a Tobin's Q of 2.2.

\section{MAIn FindingS}

In this section, we first check the validity of our identification strategy by verifying a significant discontinuity in passive institutional ownership around the Russell 1000/2000 cutoff. We then document the effect of passive institutional ownership on firms' innovation activities and strategies, using a variety of newly-developed measures.

\section{A. Discontinuities in Passive Institutional Ownership}

To begin with, we run a visual check on the discontinuity in passive institutional ownership around the Russell 1000/2000 index threshold. Figure 1 plots the percentage of passive institutional holdings relative to Russell's end-of-May capitalization rank in a narrow window centered around rank 1,000. To the left of the cutoff are the bottom 100 firms of Russell 1000 and to the right are the top 100 firms of Russell 2000. Winsorizing the variable at top and bottom 5 percent percentiles produces similar results. There is a considerable discontinuity in passive institutional ownership arising from the difference in index weights around the threshold. The non-overlapping confidence intervals suggest the statistical significance of the difference. 


\section{Figure 1. Passive Institutional Ownership around the Russell Cutoff}

Figure 1 presents the first-stage regression discontinuity results using a fitted quadratic polynomial estimate with a 95 percent confidence interval around the fitted value. To the lefthand side of the cutoff are firms in the larger Russell 1000 index, and to the right are firms in the Russell 2000 index. The sample period is 1984-2006. A superimposed scatterplot of average passive institutional ownership in each of the 40 equally-spaced bins is also presented. Within a narrow window centered on the cutoff, firms at the top of Russell 2000 have significantly higher passive institutional ownership than firms at the bottom of Russell 1000.

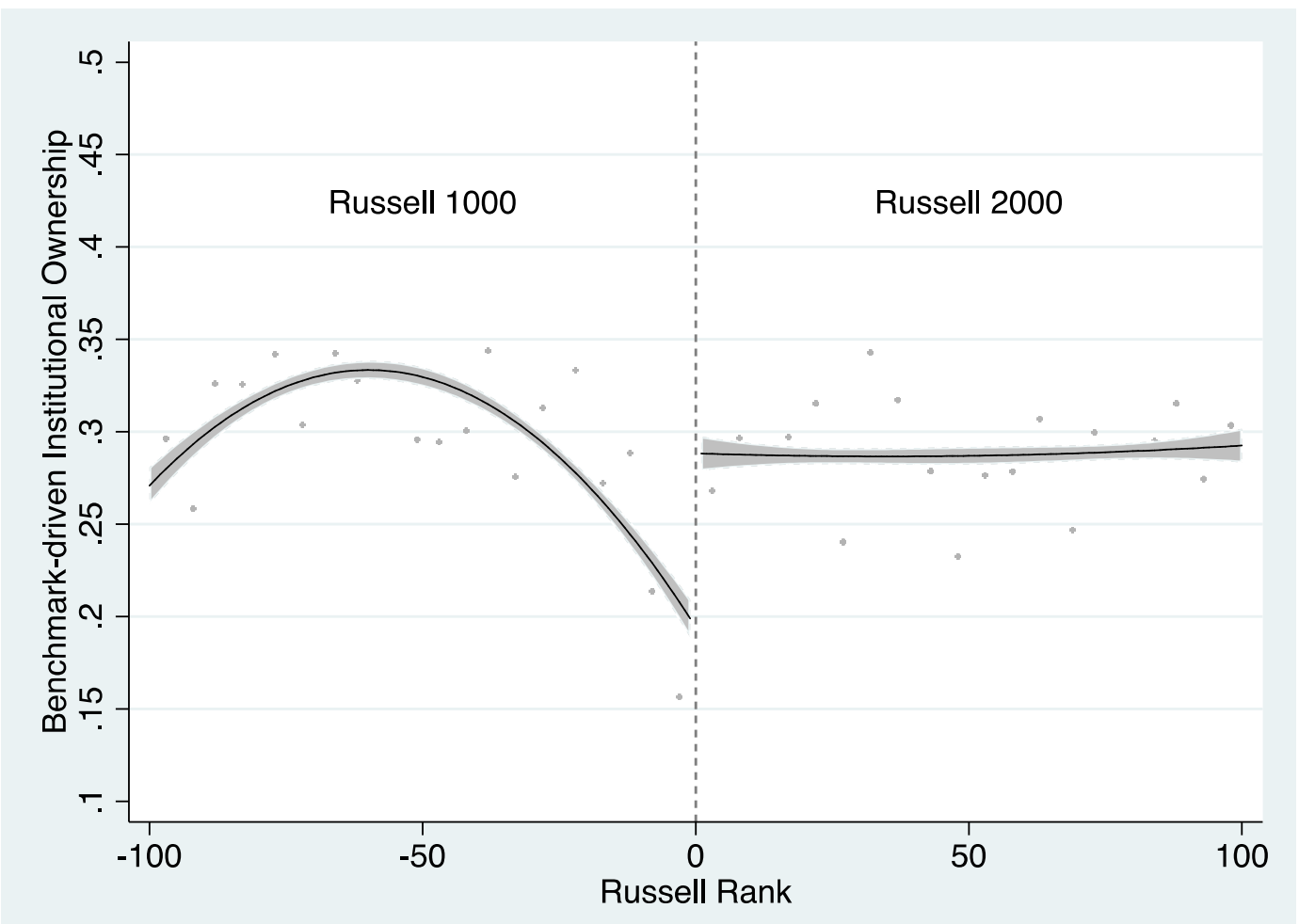

Next, we estimate equation (1) for firms within a variety of bandwidths (i.e., 100, 200, 300, and 500) around the Russell 1000/2000 index threshold and report the results in Table 2. The coefficient estimates on $R 2000$ are all positive and significant at the 5 percent or 1 percent level. Results consistently show that passive institutional ownership is significantly higher for the largest firms in Russell 2000 than the smallest firms in Russell 1000. Depending on the model specification, there is a 3-4 percent increase in passive institutional ownership due to the inclusion in Russell 2000. 


\begin{tabular}{|c|c|c|c|c|}
\hline \multicolumn{5}{|c|}{ Table 2. Passive Institutional Ownership around the Russell Cutoff } \\
\hline \multirow{2}{*}{ Variable } & Bandwidth \pm 100 & Bandwidth \pm 200 & Bandwidth \pm 300 & Bandwidth \pm 500 \\
\hline & $(1)$ & $(2)$ & $(3)$ & $(4)$ \\
\hline$R 2000$ & $\begin{array}{c}0.046 * * \\
(0.020)\end{array}$ & $\begin{array}{c}0.041 * * * \\
(0.0132)\end{array}$ & $\begin{array}{c}0.028 * * * \\
(0.0106)\end{array}$ & $\begin{array}{l}0.030 * * * \\
(0.0084)\end{array}$ \\
\hline LnAssets & $\begin{array}{c}0.011 \\
(0.009)\end{array}$ & $\begin{array}{c}0.022 * * * \\
(0.007)\end{array}$ & $\begin{array}{c}0.024 * * * \\
(0.006)\end{array}$ & $\begin{array}{c}0.028 * * * \\
(0.005)\end{array}$ \\
\hline LnAge & $\begin{array}{l}0.020 * * \\
(0.009)\end{array}$ & $\begin{array}{c}0.020 * * * \\
(0.007)\end{array}$ & $\begin{array}{c}0.019 * * * \\
(0.006)\end{array}$ & $\begin{array}{c}0.020 * * * \\
(0.005)\end{array}$ \\
\hline$R \& D$ & $\begin{array}{c}0.063 \\
(0.088)\end{array}$ & $\begin{array}{c}0.065 \\
(0.061)\end{array}$ & $\begin{array}{c}0.040 \\
(0.051)\end{array}$ & $\begin{array}{c}0.058 \\
(0.043)\end{array}$ \\
\hline Capex & $\begin{array}{l}-0.052 \\
(0.062)\end{array}$ & $\begin{array}{l}-0.044 \\
(0.051)\end{array}$ & $\begin{array}{l}-0.046 \\
(0.045)\end{array}$ & $\begin{array}{l}-0.033 \\
(0.038)\end{array}$ \\
\hline$P P E$ & $\begin{array}{l}0.038^{*} \\
(0.020)\end{array}$ & $\begin{array}{c}0.011 \\
(0.016)\end{array}$ & $\begin{array}{c}0.002 \\
(0.013)\end{array}$ & $\begin{array}{l}-0.001 \\
(0.011)\end{array}$ \\
\hline Lev & $\begin{array}{l}-0.014 \\
(0.031)\end{array}$ & $\begin{array}{c}-0.063 * * \\
(0.025)\end{array}$ & $\begin{array}{c}-0.063 * * * \\
(0.022)\end{array}$ & $\begin{array}{c}-0.062 * * * \\
(0.018)\end{array}$ \\
\hline$R O A$ & $\begin{array}{c}0.200 * * * \\
(0.043)\end{array}$ & $\begin{array}{c}0.186^{* * *} \\
(0.038)\end{array}$ & $\begin{array}{c}0.180 * * * \\
(0.034)\end{array}$ & $\begin{array}{c}0.180 * * * \\
(0.026)\end{array}$ \\
\hline$H H I$ & $\begin{array}{l}-0.219 \\
(0.525)\end{array}$ & $\begin{array}{l}-0.007 \\
(0.427)\end{array}$ & $\begin{array}{c}0.211 \\
(0.350)\end{array}$ & $\begin{array}{c}0.329 \\
(0.332)\end{array}$ \\
\hline$K Z$ & $\begin{array}{c}0.000 \\
(0.000)\end{array}$ & $\begin{array}{c}0.001 * * * \\
(0.000)\end{array}$ & $\begin{array}{c}0.000 * * \\
(0.000)\end{array}$ & $\begin{array}{l}0.000 * \\
(0.000)\end{array}$ \\
\hline Tobin's $Q$ & $\begin{array}{c}-0.005^{* *} \\
(0.003)\end{array}$ & $\begin{array}{c}-0.005^{* * *} \\
(0.002)\end{array}$ & $\begin{array}{c}-0.005 * * * \\
(0.002)\end{array}$ & $\begin{array}{c}-0.004 * * * \\
(0.001)\end{array}$ \\
\hline Firm FE & Yes & Yes & Yes & Yes \\
\hline Year FE & Yes & Yes & Yes & Yes \\
\hline Obs. & 2,284 & 4,623 & 7,035 & 11,925 \\
\hline $\operatorname{Adj.} R^{2}$ & 0.111 & 0.122 & 0.122 & 0.132 \\
\hline
\end{tabular}


Both the visual check and the regression results consistently show that firms in the top of Russell 2000 have significantly higher passive institutional holdings than firms in the bottom of Russell 1000. In the following analyses, we present the effects of passive institutional ownership changes caused by the Russell index reconstitution on firms' innovation activities.

\section{B. Innovation Activity}

In our baseline regressions, we examine the effect of passive institutional ownership on both innovation input (the ratio of a firm's annual R\&D expenses over its total assets) and innovation output (the number of patents and the number of citations received by each patent).

Table 3 presents the second-stage regression results of the 2SLS estimates described in equations (2). The coefficient estimates on $P I O$ are all positive and significant, suggesting a significant increase in both innovation input and output following an increase in passive institutional ownership caused by the Russell index reconstitution. The economic significance is sizable as well. For example, on average, a 1 percent exogenous increase in passive institutional holdings leads to a 5.4 percent increase in $R \& D$ expenses, a 4.8 percent increase in patent counts, and a 4.0 percent increase in patent citation counts three years after the index reconstitution.

\begin{tabular}{|c|c|c|c|c|c|c|}
\hline $\begin{array}{l}\text { T } \\
\text { Table } 3 \text { pr } \\
\text { by contro } \\
\text { Appendix } \\
* * * \text { denot }\end{array}$ & $\begin{array}{l}\text { 3. Effects } \\
\text { es estimate } \\
\text { for firm ar } \\
\text { hdard error } \\
\text { istical sign }\end{array}$ & $\begin{array}{l}\text { Passive Ins } \\
\text { f the effect } \\
\text { year fixed } \\
\text { re clustered } \\
\text { cance at the }\end{array}$ & $\begin{array}{l}\text { utional } \mathbf{O} \\
\text { assive ins } \\
\text { the firm le } \\
\text { percent, } 5\end{array}$ & $\begin{array}{l}\text { rship on I } \\
\text { ional own } \\
\text { is for all } \\
\text { and report } \\
\text { cent and } 1\end{array}$ & $\begin{array}{l}\text { vation } \\
\text { ip on a fi } \\
\text { bles are } \\
\text { a parentl } \\
\text { cent leve }\end{array}$ & $\begin{array}{l}\text { ity } \\
\text { innovation } \\
\text { ided in the } \\
*, * * \text {, and } \\
\text { spectively }\end{array}$ \\
\hline Variable & & & & & & \\
\hline & Year+1 & Year+3 & Year+1 & Year+3 & Year+1 & Year+3 \\
\hline & (1) & (2) & (3) & (4) & (5) & (6) \\
\hline PIO & $\begin{array}{c}6.838 * * * \\
(2.579)\end{array}$ & $\begin{array}{l}5.374 * * \\
(2.731)\end{array}$ & $\begin{array}{l}4.336 * * \\
(2.121)\end{array}$ & $\begin{array}{c}4.832 * * \\
(2.162)\end{array}$ & $\begin{array}{l}5.003 * * \\
(2.314)\end{array}$ & $\begin{array}{c}3.997 * \\
(2.225)\end{array}$ \\
\hline LnAssets & $\begin{array}{c}0.019 \\
(0.093)\end{array}$ & $\begin{array}{l}-0.005 \\
(0.093)\end{array}$ & $\begin{array}{l}-0.020 \\
(0.068)\end{array}$ & $\begin{array}{l}-0.047 \\
(0.069)\end{array}$ & $\begin{array}{l}-0.048 \\
(0.072)\end{array}$ & $\begin{array}{l}-0.040 \\
(0.489)\end{array}$ \\
\hline LnAge & $\begin{array}{c}-0.221 * * * \\
(0.071)\end{array}$ & $\begin{array}{c}-0.186^{* *} \\
(0.076)\end{array}$ & $\begin{array}{c}-0.112^{* *} \\
(0.056)\end{array}$ & $\begin{array}{c}-0.137 * * \\
(0.057)\end{array}$ & $\begin{array}{c}-0.140 * * \\
(0.057)\end{array}$ & $\begin{array}{c}-0.114^{* *} \\
(0.054)\end{array}$ \\
\hline$R \& D$ & $\begin{array}{c}12.507 * * * \\
(2.460)\end{array}$ & $\begin{array}{c}11.271 * * * \\
(2.135)\end{array}$ & $\begin{array}{c}4.672 * * * \\
(1.342)\end{array}$ & $\begin{array}{c}4.939 * * * \\
(1.392)\end{array}$ & $\begin{array}{c}3.807 * * * \\
(1.213)\end{array}$ & $\begin{array}{c}3.694 * * * \\
(1.103)\end{array}$ \\
\hline Capex & $\begin{array}{l}0.567 * \\
(0.304)\end{array}$ & $\begin{array}{c}0.342 \\
(0.327)\end{array}$ & $\begin{array}{c}0.288 \\
(0.249)\end{array}$ & $\begin{array}{c}0.358 \\
(0.273)\end{array}$ & $\begin{array}{l}0.489 * \\
(0.283)\end{array}$ & $\begin{array}{c}0.299 \\
(0.284)\end{array}$ \\
\hline$P P E$ & $\begin{array}{c}-0.338 * * * \\
(0.105)\end{array}$ & $\begin{array}{c}-0.290 * * * \\
(0.109)\end{array}$ & $\begin{array}{c}0.030 \\
(0.083) \\
\end{array}$ & $\begin{array}{r}-0.008 \\
(0.084) \\
\end{array}$ & $\begin{array}{l}-0.102 \\
(0.081)\end{array}$ & $\begin{array}{c}-0.091 \\
(0.077) \\
\end{array}$ \\
\hline
\end{tabular}




\begin{tabular}{lcccccc|}
\multirow{2}{*}{ Table 3. Effects of Passive Institutional Ownership on Innovation Activity (Concluded) } \\
\hline Variable & \multicolumn{2}{c}{ R\&D } & \multicolumn{2}{c}{ LnPat } & \multicolumn{2}{c|}{ LnCite } \\
\hline \multirow{4}{*}{ Lev } & Year+1 & Year+3 & Year+1 & Year+3 & Year+1 & Year+3 \\
\cline { 2 - 7 } & $(1)$ & $(2)$ & $(3)$ & $(4)$ & $(5)$ & $(6)$ \\
\cline { 2 - 7 } & 0.080 & 0.095 & 0.001 & 0.002 & -0.098 & -0.216 \\
ROA & $(0.218)$ & $(0.236)$ & $(0.186)$ & $(0.188)$ & $(0.199)$ & $(0.189)$ \\
& -0.476 & 0.142 & $-0.833^{*}$ & -0.711 & $-0.851^{*}$ & -0.459 \\
HHI & $(0.670)$ & $(0.662)$ & $(0.484)$ & $(0.495)$ & $(0.511)$ & $(0.489)$ \\
& 0.569 & 1.635 & -2.662 & -2.663 & $-10.282^{* * *}$ & $-9.657^{* * *}$ \\
KZ & $(2.706)$ & $(3.260)$ & $(1.895)$ & $(1.985)$ & $(2.117)$ & $(2.242)$ \\
& -0.003 & -0.002 & 0.000 & -0.000 & 0.001 & 0.002 \\
Tobin's $Q$ & $(0.002)$ & $(0.002)$ & $(0.001)$ & $(0.001)$ & $(0.002)$ & $(0.002)$ \\
& 0.010 & 0.007 & 0.017 & 0.009 & $0.033^{*}$ & 0.016 \\
Firm FE & $(0.021)$ & $(0.023)$ & $(0.016)$ & $(0.017)$ & $(0.018)$ & $(0.017)$ \\
Year FE & Yes & Yes & Yes & Yes & Yes & Yes \\
Obs. & Yes & Yes & Yes & Yes & Yes & Yes \\
Adj. $R^{2}$ & 7,035 & 7,035 & 7,035 & 7,035 & 7,035 & 7,035 \\
& 0.490 & 0.406 & 0.292 & 0.277 & 0.269 & 0.270 \\
& & & & & & \\
\hline
\end{tabular}

Figures 2 and 3 show the discontinuity in the number of patents and the number of citations per patent, respectively, around the Russell 1000/2000 cutoff three years after the index reconstitution. We observe that, within close proximity of the cutoff, patent and citation counts jump significantly once the ranking moves across the threshold from Russell 1000 to Russell 2000. This graphic analysis confirms the positive effect of institutional investors on patent and citation counts. 
Figure 2. Patent Counts Around the Russell Cutoff

Figure 2 presents the second-stage regression discontinuity results using a fitted quadratic polynomial estimate with a 95 percent confidence interval around the fitted value. To the lefthand side of the cutoff are firms in the larger Russell 1000 index, and to the right are firms in the Russell 2000 index. The sample period is 1984-2006. A superimposed scatterplot of average patent counts in each of the 40 equally-spaced bins is also presented. Within a narrow window centered on the cutoff, firms at the top of Russell 2000 produce significantly more patent counts than firms at the bottom of Russell 1000 three years after the index reconstitution.

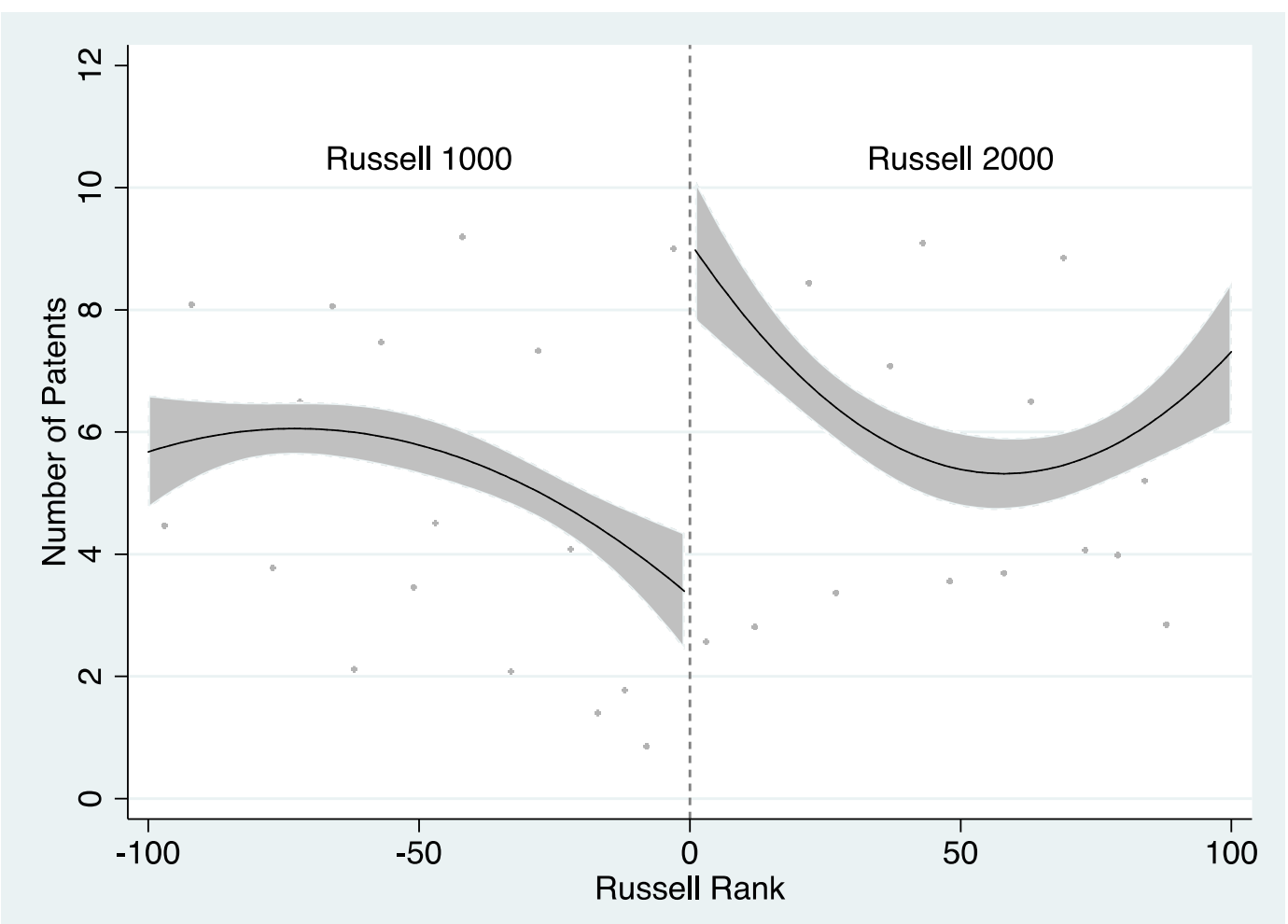




\section{Figure 3. Citation Counts Around the Russell Cutoff}

Figure 3 presents the second-stage regression discontinuity results using a fitted quadratic polynomial estimate with a 95 percent confidence interval around the fitted value. To the lefthand side of the cutoff are firms in the larger Russell 1000 index, and to the right are firms in the Russell 2000 index. The sample period is 1984-2006. A superimposed scatterplot of average citation counts per patent in each of the 40 equally-spaced bins is also presented. Within a narrow window centered on the cutoff, firms at the top of Russell 2000 produce significantly more citation counts than firms at the bottom of Russell 1000 three years after the index reconstitution.

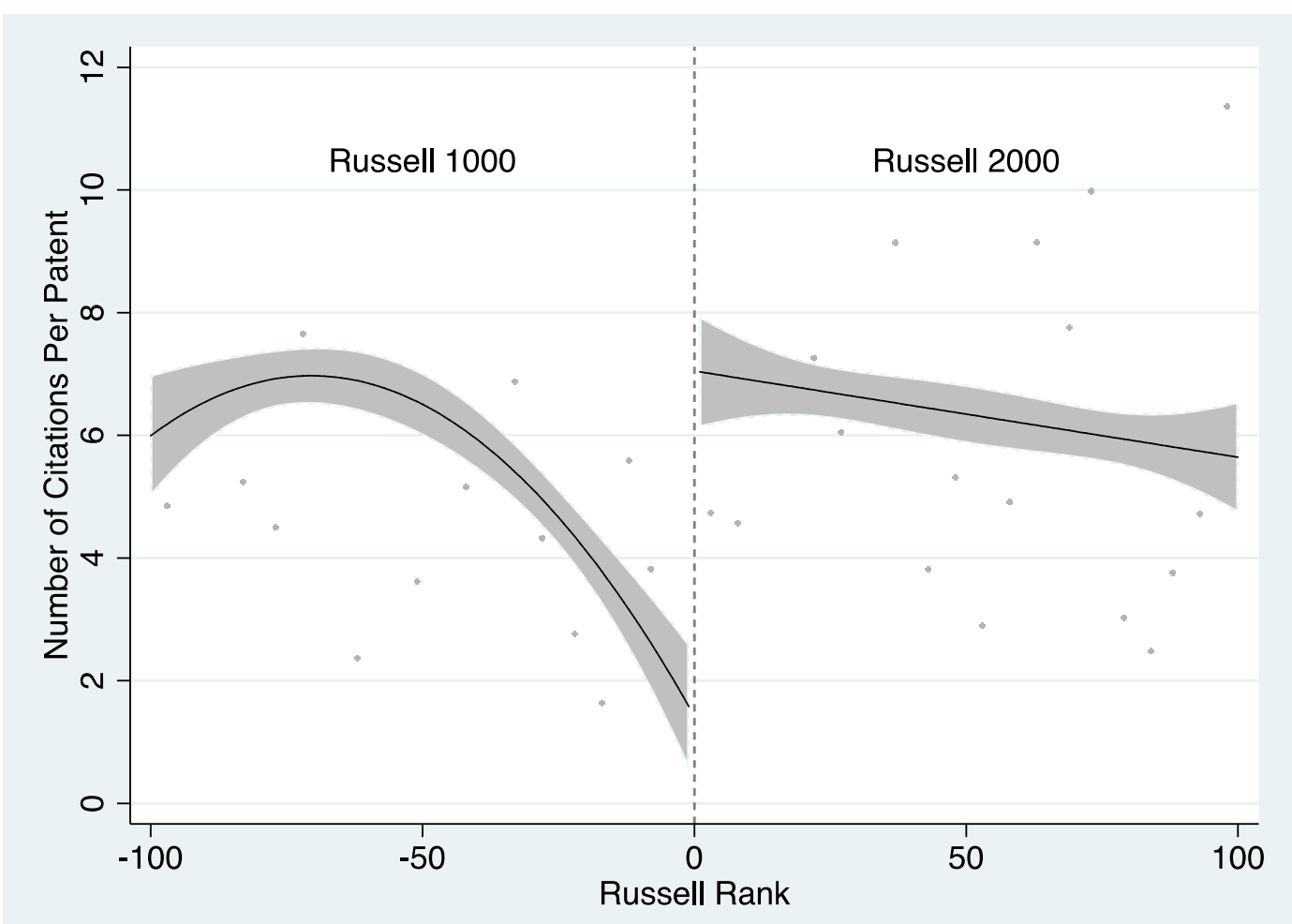

\section{Innovation Strategy}

As discussed earlier, R\&D expenditure and patents are crude measures of firm-level innovation. These measures cannot tap into the full technological and economic dimensions of innovation output, nor do they reveal the fundamental value and nature of innovation search. To enable a deeper understanding of a firm's innovation strategy, we continue with the analysis using multiple dimensions of patent and citation characteristics.

Matutes et al. (1996) point out that patent protection regimes, particularly the length and scope of patent protection, induce early disclosure of fundamental innovation. The two indicators that are of particular interest to our study are claim number and claim length, since 
they have been proven to be closely related with the scope of a patent (USPTO, 2019). ${ }^{6}$ As the number and length of patent claims increase, the scope of a patent narrows. If a firm introduces a radical innovation that makes a broad contribution to the field, its patent is likely to be broad in scope and have short claims. On the contrary, if a firm is making a marginal contribution to an already crowded area, the claims of its patents are expected to be longer and narrower in scope. In columns (1) and (2) of Table 4 Panel A in which claim number and claim length are the dependent variables, respectively, the coefficient estimates on PIO are both positive and significant at the 1 percent level, suggesting that, after institutional investors increase their holdings, firms undertake research in more crowded and mature areas of technology. As a result, they have to impose more scope conditions when applying for relevant patents in order to be differentiated from existing patents.

\section{Table 4. Effects of Passive Institutional Ownership on Innovation Strategy}

Table 4 provides estimates of the effect of passive institutional ownership on various dimensions of a firm's innovation by controlling for firm and year fixed effects. Definitions for all variables are provided in the Appendix. Standard errors are clustered at the firm level and reported in parentheses. $*, * *$, and $* * *$ denote statistical significance at the 10 percent, 5 percent and 1 percent levels, respectively.

\begin{tabular}{lccccc}
\hline \multirow{2}{*}{ Panel A } & \multicolumn{5}{c}{ Patent Claims and Citation Distribution } \\
\hline Variable & ClaimNo & ClaimLength & Breakthrough & Failure & Incremental \\
\cline { 2 - 6 } & $(1)$ & $(2)$ & $(3)$ & $(4)$ & $(5)$ \\
\hline \multirow{2}{*}{ PIO } & $6.678^{* * *}$ & $9.332^{* * *}$ & 3.643 & 1.991 & $5.621^{*}$ \\
& $(2.411)$ & $(3.382)$ & $(2.572)$ & $(1.897)$ & $(3.303)$ \\
LnAssets & -0.105 & -0.121 & 0.038 & 0.053 & 0.110 \\
& $(0.073)$ & $(0.104)$ & $(0.082)$ & $(0.052)$ & $(0.101)$ \\
R\&D & $-0.134 * *$ & $-0.172 * *$ & $-0.173 * * *$ & -0.039 & -0.079 \\
Capex & $(0.062)$ & $(0.087)$ & $(0.059)$ & $(0.051)$ & $(0.083)$ \\
& $3.739 * * *$ & $5.461 * * *$ & $2.329 * * *$ & $1.904 * * *$ & -0.630 \\
PPE & $(1.225)$ & $(1.769)$ & $(0.629)$ & $(0.433)$ & $(0.679)$ \\
& 0.187 & 0.331 & $1.050 * *$ & -0.176 & 0.446 \\
Lev & $(0.280)$ & $(0.402)$ & $(0.433)$ & $(0.397)$ & $(0.655)$ \\
& 0.016 & -0.000 & -0.119 & 0.169 & 0.096 \\
ROA & $(0.092)$ & $(0.129)$ & $(0.112)$ & $(0.110)$ & $(0.142)$ \\
& 0.159 & 0.173 & -0.314 & -0.145 & -0.179 \\
& $(0.201)$ & $(0.284)$ & $(0.247)$ & $(0.164)$ & $(0.287)$ \\
& $-1.623 * * *$ & $-2.015 * * *$ & -0.537 & $-0.695 *$ & -0.630 \\
& $(0.511)$ & $(0.721)$ & $(0.510)$ & $(0.416)$ & $(0.679)$ \\
\hline
\end{tabular}

${ }^{6}$ United States Patent and Trademark Office, 2019. Patent Claims Methodology. Available at https://www.uspto.gov/sites/default/files/documents/patent_claims_methodology.pdf 


\begin{tabular}{|c|c|c|c|c|c|}
\hline \multirow{3}{*}{$\begin{array}{c}\text { Panel A } \\
\text { Variable }\end{array}$} & \multicolumn{5}{|c|}{ Patent Claims and Citation Distribution } \\
\hline & ClaimNo & ClaimLength & Breakthrough & Failure & Incremental \\
\hline & (1) & $(2)$ & (3) & (4) & $(5)$ \\
\hline$H H I$ & $\begin{array}{c}-7.161 * * * \\
(2.301)\end{array}$ & $\begin{array}{c}-12.960 * * \\
(3.288)\end{array}$ & $\begin{array}{c}0.868 \\
(2.895)\end{array}$ & $\begin{array}{c}0.282 \\
(2.456)\end{array}$ & $\begin{array}{l}-2.411 \\
(3.759)\end{array}$ \\
\hline$K Z$ & $\begin{array}{l}-0.000 \\
(0.001)\end{array}$ & $\begin{array}{c}0.000 \\
(0.000)\end{array}$ & $\begin{array}{c}0.001 \\
(0.001)\end{array}$ & $\begin{array}{l}-0.001 \\
(0.001)\end{array}$ & $\begin{array}{c}0.002 \\
(0.002)\end{array}$ \\
\hline Tobin's $Q$ & $\begin{array}{c}0.058 * * * \\
(0.018)\end{array}$ & $\begin{array}{c}0.066^{* * *} \\
(0.025)\end{array}$ & $\begin{array}{l}-0.012 \\
(0.018)\end{array}$ & $\begin{array}{c}0.006 \\
(0.012)\end{array}$ & $\begin{array}{c}0.021 \\
(0.022)\end{array}$ \\
\hline Firm FE & Yes & Yes & Yes & Yes & Yes \\
\hline Year FE & Yes & Yes & Yes & Yes & Yes \\
\hline Obs. & 7,035 & 7,035 & 2,463 & 2,463 & 2,463 \\
\hline Adj. $R^{2}$ & 0.287 & 0.283 & 0.129 & 0.322 & 0.168 \\
\hline Panel B & \multicolumn{5}{|c|}{ Technological Value and Product Introduction } \\
\hline \multirow[t]{2}{*}{ Variable } & NewField & \multicolumn{2}{|c|}{ Originality } & Generality & Product \\
\hline & (1) & & ) & (3) & $(4)$ \\
\hline$P I O$ & $\begin{array}{c}3.926 \\
(3.511)\end{array}$ & $\begin{array}{r}-1.6 \\
(0 .\end{array}$ & $\begin{array}{l}55 * * \\
756)\end{array}$ & $\begin{array}{l}-1.462 * \\
(0.827)\end{array}$ & $\begin{array}{l}-0.440 * \\
(0.245)\end{array}$ \\
\hline LnAssets & $\begin{array}{c}0.168 \\
(0.108)\end{array}$ & $\begin{array}{r}0 . \\
(0 .\end{array}$ & $\begin{array}{l}15 \\
22)\end{array}$ & $\begin{array}{l}-0.004 \\
(0.024)\end{array}$ & $\begin{array}{c}0.009 \\
(0.007)\end{array}$ \\
\hline LnAge & $\begin{array}{l}-0.043 \\
(0.089)\end{array}$ & $\begin{array}{l}0.0 \\
(0 .\end{array}$ & $\begin{array}{l}9 * * \\
18)\end{array}$ & $\begin{array}{c}0.048 * * \\
(0.020)\end{array}$ & $\begin{array}{c}0.005 \\
(0.005)\end{array}$ \\
\hline$R \& D$ & $\begin{array}{c}4.842 * * * \\
(0.894)\end{array}$ & $\begin{array}{l}0 . \\
(0 .\end{array}$ & $\begin{array}{l}21 \\
00)\end{array}$ & $\begin{array}{l}-0.019 \\
(0.100)\end{array}$ & $\begin{array}{c}0.168 * * \\
(0.066)\end{array}$ \\
\hline Capex & $\begin{array}{c}0.296 \\
(0.694)\end{array}$ & $\begin{array}{r}-0.48 \\
(0 .\end{array}$ & $\begin{array}{l}3 * * * \\
53)\end{array}$ & $\begin{array}{c}-0.319 * * \\
(0.152)\end{array}$ & $\begin{array}{c}0.016 \\
(0.027)\end{array}$ \\
\hline$P P E$ & $\begin{array}{c}0.133 \\
(0.162)\end{array}$ & $\begin{array}{r}0 . \\
(0 .\end{array}$ & 27 & $\begin{array}{l}0.054 * \\
(0.032)\end{array}$ & $\begin{array}{l}-0.004 \\
(0.006)\end{array}$ \\
\hline Lev & $\begin{array}{l}-0.398 \\
(0.319)\end{array}$ & $\begin{array}{l}0 . \\
(0 .\end{array}$ & 41 & $\begin{array}{c}0.009 \\
(0.075)\end{array}$ & $\begin{array}{c}-0.023 \\
(0.018)\end{array}$ \\
\hline$R O A$ & $\begin{array}{l}-0.548 \\
(0.723)\end{array}$ & $\begin{array}{r}0 . \\
(0 .\end{array}$ & $\begin{array}{l}40 \\
46)\end{array}$ & $\begin{array}{c}0.093 \\
(0.160)\end{array}$ & $\begin{array}{c}0.032 \\
(0.046)\end{array}$ \\
\hline$H H I$ & $\begin{array}{l}-6.252 \\
(4.785)\end{array}$ & $\begin{array}{l}2.0 \\
(0 .\end{array}$ & $\begin{array}{l}39 * * \\
52) \\
\end{array}$ & $\begin{array}{c}2.842 * * * \\
(1.042)\end{array}$ & $\begin{array}{l}-0.145 \\
(0.443)\end{array}$ \\
\hline
\end{tabular}


Table 4. Effects of Passive Institutional Ownership on Innovation Strategy (Concluded)

\begin{tabular}{|lcccc|}
\hline \multicolumn{1}{c}{ Panel B } & \multicolumn{4}{c|}{ Technological Value and Product Introduction } \\
\hline Variable & NewField & Originality & Generality & Product \\
\cline { 2 - 5 } & $(1)$ & $(2)$ & $(3)$ & $(4)$ \\
\hline KZ & 0.001 & $0.001^{*}$ & 0.000 & 0.000 \\
& $(0.001)$ & $(0.001)$ & $(0.001)$ & $(0.000)$ \\
Tobin's $Q$ & 0.008 & -0.006 & -0.008 & $-0.004^{* * *}$ \\
& $(0.024)$ & $(0.005)$ & $(0.006)$ & $(0.002)$ \\
Firm FE & Yes & Yes & Yes & Yes \\
Year FE & Yes & Yes & Yes & Yes \\
Obs. & 2,463 & 2,185 & 1,896 & 3,808 \\
Adj. $R^{2}$ & 0.200 & 0.031 & 0.048 & 0.054 \\
& & & & \\
\hline
\end{tabular}

Motivated by the argument that commercial value is heavily skewed in favor of highly cited patents (Hall et al., 2005), we next explore whether institutions have influences on the citation distribution of a firm's patents. We categorize patents into breakthroughs, failures, and incremental innovations based on their positions in the citation distribution of all patents filed in the same technology class in the same year. As one can observe from columns (3) and (4) in which the dependent variables are breakthrough and failed innovation, respectively, the coefficient estimates on $P I O$ are both statistically insignificant. The coefficient estimate on PIO in column (5) in which incremental innovation is the dependent variable, however, is positive and significant. These findings suggest that, to the extent that breakthrough and failed patents represent risky but potentially influential innovation, institutional investors appear to promote quantifiable but incremental innovation at the expense of risky but novel innovation that is more likely to either make a breakthrough or fail completely.

We then investigate the technological features of a firm's innovation search. According to Jaffe (1989), the technological proximity between newly filed patents and the existing patent portfolio held by the same firm reflects whether the firm stays in or deviates from familiar innovation areas. We use NewField to capture technological proximity. Our hypothesis is that, if a firm's main aim is to push its knowledge boundaries outwards, we should observe more patents produced in new technology classes. If, however, a firm's goal is mostly to make marginal upgrades to current products, it focuses more on existing technologies in its portfolio. We replace the dependent variable with NewField and report the regression results in Panel B column (1). The coefficient estimate on PIO is statistically insignificant, suggesting that an increase in passive institutional ownership does not seem to push firms to expand their innovation landscape into new, unknown fields.

Another proxy that captures the technology overlap between a patent and the prior art is patent originality score. Inventions that draw inspiration from a larger number of diverse knowledge sources are supposed to generate original outcomes (Trajtenberg et al., 1997). We 
report the regression result with the dependent variable replaced by patent originality score in Panel B column (2). The coefficient estimate on $P I O$ is negative and significant, suggesting that an increase in passive institutional ownership leads to a significantly lower patent originality score. In other words, firms are more inclined to focus on incremental research rather than novel creation.

We then use patent generality score to capture a patent's fundamental nature and its influence to subsequent patents. Specifically, it assesses the range of later generations of invention that have benefited from a certain patent. On a scale from zero to one, the value of the generality score is higher if a patent is cited by subsequent patents belonging to a wider range of technology classes. We replace the dependent variable with patent generality score in Panel $\mathrm{B}$ column (3). The coefficient estimate on $P I O$ is negative and significant, suggesting a significant reduction in patent generality score after an increase in passive institutional ownership, i.e., firms appear to narrow down their innovation search towards more specialized fields with less value for general application.

In addition to patent-based innovation measures, we collect information on firms' new product releases. Launching new products, after all, is the ultimate way to realize the commercial value of innovation. If a firm obtains patents but decides not to develop them into new commercial products, then the firm is likely to use the patents to defend its current products from competitors (i.e., strategic roles), rather than to reap profits from commercialization (i.e., productive roles) (Blundell et al., 1999). In column (4) of Table 4 Panel B, we replace the dependent variable with the number of new products released by a firm. The coefficient estimate on $P I O$ is negative and significant, suggesting that, despite an increase in patent counts, there is a significant drop in the number of new products after increases in passive institutional ownership. Firms increase strategic rather than productive use of their patents.

Putting all the empirical evidence together, we find that while firms' R\&D expenditures, patent counts, and citation counts increase with a larger percentage of passive institutional holdings, there is a growing tendency for firms to exploit existing technologies instead of exploring new technological areas and pursuing breakthrough innovation. The change in innovation can be observed one year after the change in passive institutional ownership, which is relatively quick given that innovation needs time to be planned, implemented and ultimately patented. It is precisely because exploitative innovation, which means inventors deliberately look for readily patentable technology within the firm's existing portfolio, is easier to execute than explorative innovation, which is marked by prolonged planning and uncertain payback.

\section{Plausible Underlying Channels}

Our baseline results reveal a subtle relation between passive institutional shareholders and innovation. We propose two plausible underlying channels that explain our baseline findings. On the one hand, consistent with the classic agency theory, intensified monitoring by institutional investors leads to increased effort of the agent and hence increases a firm's innovation input (measured by R\&D expenditures) and innovation output (measured by patent and citation counts). We term it as the monitoring channel. On the other hand, it is 
possible that passive institutional investors significantly change the firm's innovation strategy by focusing on patentable technologies within the firm's current portfolio instead of seeking to break new grounds. This shift in a firm's innovation focus and strategy could be driven by the risk aversion on the part of passive institutional investors who demand immediate, countable results, or because the large block held by institutional shareholders alters managers' incentive schemes, weakens their power, and aggravates their career concerns. As a consequence, managers exhibit greater risk aversion and shift to more conservative exploitation in instead of aggressive exploration. We term this argument the incentive channel. We explore these two plausible economic channels below.

\section{A. Monitoring}

Agency theory assumes that tighter monitoring by the principal should motivate agents to increase their effort. Thus, managers may prefer a quiet life (e.g., Bertrand and Mullainathan, 2003) but increased monitoring by institutional investors forces them to exert more effort on innovation and generate more observable and countable innovation output. We test the monitoring channel by starting with an examination of shareholder voting behavior following the change in institutional ownership. As Kahan and Rock (2007) note, "Never has voting been more important in corporate law." As one of the central and observable components of shareholder monitoring, voting at annual shareholder meetings is, ultimately, the real mechanism by which shareholders directly influence corporate policies. As a result, regulators have called for greater participation to ensure better monitoring. ${ }^{7}$ The ISS/RiskMetrics Voting Analytics database contains details of mutual fund votes, including meeting date, agenda, management recommendation as well as fund voting result. We identify index-tracking institutions as passive institutional investors and calculate their participation rate in shareholder meetings at the firm level in the year following the index reconstitution. Due to the availability of voting data, our sample period for this test starts from 2003.

Using the instrumental variable framework discussed earlier, we estimate the effect of passive institutional ownership on vote participation and report the results in Table 5. As one can observe from column (1), the coefficient estimate on $P I O$ is positive and significant at the 1 percent level. The magnitude of the coefficient estimate suggests that a 1 percent increase in holdings by passive institutional investors is associated with an approximately 1.4 percent increase in their vote participation. Fewer passive investors abstain, withhold, or free-ride on other voters by simply choosing not to vote. The results are consistent with the prior literature that passive investors vote actively (Fisch et al., 2019) and act as substitutes for other governance mechanisms (Gillan and Starks, 2003).

\footnotetext{
${ }^{7}$ U.S. Securities and Exchange Commission, 2015. Proxy Voting Roundtable. Available at https://www.sec. gov/spotlight/proxy-voting-roundtable/proxy-voting-roundtable-transcript.txt.
} 


\section{Table 5. The Monitoring Channel}

Table 5 provides estimates of the effects on the voting behavior of passive institutional investors. Standard errors are clustered at the firm level and reported in parentheses. Definitions for all variables are provided in the Appendix. *,**, and *** denote statistical significance at the 10 percent, 5 percent and 1 percent levels, respectively.

\begin{tabular}{|c|c|c|c|c|}
\hline \multirow[t]{2}{*}{ Variable } & $\begin{array}{c}\text { Vote } \\
\text { Participation }\end{array}$ & $\begin{array}{c}\text { Vote For } \\
\text { Percentage }\end{array}$ & $\begin{array}{c}\text { Vote Against } \\
\text { Percentage }\end{array}$ & $\begin{array}{l}\text { Disagree with } \\
\text { Management }\end{array}$ \\
\hline & (1) & $(2)$ & (3) & (4) \\
\hline \multirow[t]{2}{*}{$\mathrm{PIO}$} & $1.422 * * *$ & $1.136 * *$ & 0.287 & $-1.203 * *$ \\
\hline & $(0.473)$ & $(0.576)$ & $(0.324)$ & $(0.580)$ \\
\hline \multirow[t]{2}{*}{ Lnassets } & $-0.026^{*}$ & -0.021 & -0.05 & 0.022 \\
\hline & $(0.013)$ & $(0.017)$ & (0.009) & $(0.017)$ \\
\hline \multirow[t]{2}{*}{ Lnage } & $-0.021 * *$ & -0.012 & -0.009 & 0.012 \\
\hline & $(0.011)$ & $(0.013)$ & $(0.007)$ & $(0.013)$ \\
\hline \multirow[t]{2}{*}{$R \& D$} & -0.049 & -0.122 & 0.073 & 0.115 \\
\hline & $(0.087)$ & $(0.119)$ & $(0.083)$ & $(0.120)$ \\
\hline \multirow[t]{2}{*}{ Capex } & -0.034 & -0.089 & 0.055 & 0.085 \\
\hline & $(0.079)$ & $(0.095)$ & $(0.057)$ & $(0.094)$ \\
\hline \multirow[t]{2}{*}{$P P E$} & 0.012 & 0.023 & -0.011 & -0.023 \\
\hline & $(0.012)$ & $(0.016)$ & $(0.009)$ & $(0.015)$ \\
\hline \multirow[t]{2}{*}{ Lev } & $0.094 * * *$ & $0.071 *$ & 0.023 & -0.059 \\
\hline & $(0.034)$ & $(0.041)$ & $(0.025)$ & $(0.042)$ \\
\hline \multirow[t]{2}{*}{$R O A$} & $-0.251 * *$ & -0.193 & -0.058 & 0.202 \\
\hline & $(0.105)$ & $(0.128)$ & $(0.066)$ & $(0.128)$ \\
\hline \multirow[t]{2}{*}{$H H I$} & 1.073 & -0.278 & $1.352 * *$ & $0.253 * *$ \\
\hline & (1.740) & (1.933) & $(0.653)$ & (1.917) \\
\hline \multirow[t]{2}{*}{$K Z$} & -0.000 & 0.000 & -0.000 & -0.000 \\
\hline & $(0.000)$ & $(0.000)$ & $(0.000)$ & $(0.000)$ \\
\hline \multirow[t]{2}{*}{ Tobin's $Q$} & $0.011 * *$ & $0.011 *$ & -0.000 & $-0.011 *$ \\
\hline & $(0.005)$ & $(0.006)$ & $(0.004)$ & $(0.006)$ \\
\hline Firm FE & Yes & Yes & Yes & Yes \\
\hline Year FE & Yes & Yes & Yes & Yes \\
\hline Obs. & 1,259 & 1,259 & 1,259 & 1,259 \\
\hline Adj. $R^{2}$ & 0.017 & 0.015 & 0.029 & 0.017 \\
\hline
\end{tabular}


We further investigate passive investors' attitudes on various corporate agendas. In columns (2) and (3) in which we replace the dependent variable with Vote For Percentage (defined as the number of meetings in which passive investors cast a "For" vote over the total number of meetings) and Vote Against Percentage (defined as the number of meetings in which passive investors cast an "Against" vote over the total number of meetings), respectively. The coefficient estimate on PIO in column (2) is positive and significant, suggesting that, on a range of issues from board elections to incentive plans, passive investors cast significantly more votes in support of the proposals. Meanwhile, the coefficient estimate on PIO in column (3) is insignificant, indicating that the percentage of opposing votes does not change significantly. These observations can be the result of the confluence of two factors: on the one hand, since passive institutional investors vote based on proxy-voting recommendations, a higher support level indicates a growing number of proposals are being submitted in accordance with proxy-voting protocols - sponsors are unlikely to seek ballot on a proposal if they do not anticipate support from large shareholders. On the other hand, institutional investors become less dissenting as their shareholdings increase.

Finally, we analyze to what extent passive institutional investors' votes agree or disagree with management recommendations. We replace the dependent variable with Disagree with Management, which is the ratio of the number of meetings in which passive funds' vote is different from management vote recommendation over the total number of meetings, and report the regression result in column (4). The coefficient estimate on $P I O$ is negative and significant, suggesting that an increase in passive institutional ownership leads to fewer shareholder-manager conflicts in the board room. In other words, with the increase in passive institutional holdings, managers start to face a more compliant shareholder population.

In summary, our findings in this subsection are consistent with the existing literature (Bethel and Gillan, 2002) that as institutional investors hold more shares of the firm, they are more likely to garner sufficient benefits from voting to justify their monitoring costs than those with fewer shares. Increased monitoring from institutional shareholders pushes managers to exert more effort, which leads to more observable innovation outcomes, such as a larger number of registered patents.

\section{B. Incentive}

Risk-averse investors could alter managers' incentives and induce them to change their innovation strategies by focusing more on exploitative as opposed to exploratory innovation. In addition, passive institutional investors could affect a firm's governance (Appel et al., 2016) and reduce top management entrenchment, which could affect a firm's innovation strategy as well.

To test the incentive and governance channel, we first obtain CEO turnover data from Execucomp. We define Forced Turnover as a dummy that takes the value of one if there is a CEO replacement for reasons other than "deceased" or "retired" before the age of 60 in a year, and zero otherwise. We construct four variables to capture a firm's financial and stock market performance: $\triangle R O A(\triangle R e t)$ is a dummy that equals one if a firm's return on assets (stock return) is lower than that in the previous year and zero otherwise; IndROA (IndRet) is 
a dummy that equals one if a firm's return on assets (stock return) is lower than the industry median and zero otherwise. The main variables of interest are the interaction terms between $P I O$ and various performance measures.

\begin{tabular}{|c|c|c|c|c|c|c|}
\hline $\begin{array}{l}\text { Table } 6 \text { provid } \\
\text { managerial en } \\
\text { provided in th } \\
\text { parentheses. } \\
\text { percent levels, }\end{array}$ & $\begin{array}{l}\text { estimates } \\
\text { enchment } \\
\text { Appendix } \\
* * \text {, and ** } \\
\text { espectively }\end{array}$ & $\begin{array}{l}\text { Table 6. } \\
\text { the effect } \\
\text { Panels A } \\
\text { Standard e } \\
\text { denote stat }\end{array}$ & $\begin{array}{l}\text { e Incentive } \\
\text { assive inst } \\
\text { d B, respe } \\
\text { rs are clus } \\
\text { cal signific }\end{array}$ & $\begin{array}{l}\text { Channel } \\
\text { tional owne } \\
\text { vely. Defin } \\
\text { ed at the } \\
\text { ce at the } 1\end{array}$ & $\begin{array}{l}\text { hip on } C E \\
\text { ons for al } \\
\text { m level a1 } \\
\text { percent, } 5\end{array}$ & $\begin{array}{l}\text { urnover and } \\
\text { ariables are } \\
\text { reported in } \\
\text { rcent and } 1\end{array}$ \\
\hline Panel A & & $\mathrm{CE}$ & Turnover & d Compen & tion & \\
\hline Variable & $\begin{array}{c}\text { Forced } \\
\text { turnover }\end{array}$ & $\begin{array}{c}\text { Forced } \\
\text { turnover }\end{array}$ & $\begin{array}{c}\text { Forced } \\
\text { turnover }\end{array}$ & $\begin{array}{c}\text { Forced } \\
\text { turnover }\end{array}$ & $\begin{array}{c}\text { Forced } \\
\text { turnover }\end{array}$ & Vega \\
\hline & (1) & (2) & (3) & (4) & (5) & (6) \\
\hline $\mathrm{PIO}$ & $\begin{array}{c}7.941 * * \\
(3.880)\end{array}$ & $\begin{array}{c}8.247 * * \\
(3.891)\end{array}$ & $\begin{array}{c}9.090 * * \\
(4.094)\end{array}$ & $\begin{array}{c}8.107 * * \\
(3.889)\end{array}$ & $\begin{array}{c}8.089 * * \\
(3.897)\end{array}$ & $\begin{array}{c}2.337 \\
(2.623)\end{array}$ \\
\hline$P I O^{*} \triangle R O A$ & & $\begin{array}{c}0.585 * * * \\
(0.158)\end{array}$ & & & & \\
\hline$P I O * \operatorname{IndROA}$ & & & $\begin{array}{c}0.405 * * \\
(0.189)\end{array}$ & & & \\
\hline$P I O * \Delta R e t$ & & & & $\begin{array}{c}0.500 * * * \\
(0.168)\end{array}$ & & \\
\hline PIO*IndRet & & & & & $\begin{array}{c}0.640 * * * \\
(0.156)\end{array}$ & \\
\hline LnAssets & $\begin{array}{l}-0.091 \\
(0.103)\end{array}$ & $\begin{array}{l}-0.100 \\
(0.103)\end{array}$ & $\begin{array}{l}-0.149 \\
(0.109)\end{array}$ & $\begin{array}{l}-0.086 \\
(0.103)\end{array}$ & $\begin{array}{l}-0.121 \\
(0.104)\end{array}$ & $\begin{array}{l}-0.046 \\
(0.107)\end{array}$ \\
\hline LnAge & $\begin{array}{l}-0.001 \\
(0.084)\end{array}$ & $\begin{array}{l}-0.007 \\
(0.084)\end{array}$ & $\begin{array}{l}-0.013 \\
(0.088)\end{array}$ & $\begin{array}{c}0.001 \\
(0.084)\end{array}$ & $\begin{array}{l}-0.003 \\
(0.084)\end{array}$ & $\begin{array}{c}-0.130 * \\
(0.067)\end{array}$ \\
\hline$R \& D$ & $\begin{array}{c}0.113 \\
(0.471)\end{array}$ & $\begin{array}{c}0.049 \\
(0.477)\end{array}$ & $\begin{array}{c}0.032 \\
(0.496)\end{array}$ & $\begin{array}{c}0.187 \\
(0.471)\end{array}$ & $\begin{array}{c}0.154 \\
(0.474)\end{array}$ & $\begin{array}{l}0.892 * \\
(0.511)\end{array}$ \\
\hline Capex & $\begin{array}{c}0.899 * * \\
(0.434)\end{array}$ & $\begin{array}{c}0.863 * * \\
(0.437)\end{array}$ & $\begin{array}{c}1.209 * * * \\
(0.451)\end{array}$ & $\begin{array}{c}0.902 * * \\
(0.433)\end{array}$ & $\begin{array}{l}0.847 * \\
(0.436)\end{array}$ & $\begin{array}{c}1.174 * * \\
(0.468)\end{array}$ \\
\hline$P P E$ & $\begin{array}{l}-0.070 \\
(0.093)\end{array}$ & $\begin{array}{c}-0.061 \\
(0.093)\end{array}$ & $\begin{array}{l}-0.121 \\
(0.104)\end{array}$ & $\begin{array}{c}-0.065 \\
(0.093)\end{array}$ & $\begin{array}{c}-0.072 \\
(0.093)\end{array}$ & $\begin{array}{c}-0.462 * * * \\
(0.097)\end{array}$ \\
\hline Lev & $\begin{array}{c}0.253 \\
(0.277)\end{array}$ & $\begin{array}{c}0.292 \\
(0.278)\end{array}$ & $\begin{array}{c}0.387 \\
(0.292)\end{array}$ & $\begin{array}{c}0.248 \\
(0.278)\end{array}$ & $\begin{array}{c}0.288 \\
(0.278)\end{array}$ & $\begin{array}{c}0.216 \\
(0.232)\end{array}$ \\
\hline$R O A$ & $\begin{array}{l}-0.991 \\
(0.732)\end{array}$ & $\begin{array}{c}-1.217^{*} \\
(0.736)\end{array}$ & $\begin{array}{l}-1.068 \\
(0.778)\end{array}$ & $\begin{array}{c}-0.998 \\
(0.734)\end{array}$ & $\begin{array}{l}-1.021 \\
(0.735)\end{array}$ & $\begin{array}{l}-0.237 \\
(0.577)\end{array}$ \\
\hline
\end{tabular}




\begin{tabular}{|c|c|c|c|c|c|c|}
\hline \multicolumn{7}{|c|}{ Table 6. The Incentive Channel (Continued) } \\
\hline Panel A & \multicolumn{6}{|c|}{$\begin{array}{l}\text { CEO Turnover and Compensation } \\
\end{array}$} \\
\hline \multirow[t]{2}{*}{ Variable } & $\begin{array}{l}\text { Forced } \\
\text { turnover }\end{array}$ & $\begin{array}{c}\text { Forced } \\
\text { turnover }\end{array}$ & $\begin{array}{l}\text { Forced } \\
\text { turnover }\end{array}$ & $\begin{array}{c}\text { Forced } \\
\text { turnover }\end{array}$ & $\begin{array}{l}\text { Forced } \\
\text { turnover }\end{array}$ & Vega \\
\hline & $(1)$ & (2) & (3) & (4) & $(5)$ & (6) \\
\hline \multirow[t]{2}{*}{$H H I$} & 0.655 & 0.563 & 0.424 & 0.895 & 0.714 & 0.207 \\
\hline & $(3.370)$ & $(3.380)$ & $(3.508)$ & $(3.375)$ & $(3.388)$ & $(3.807)$ \\
\hline \multirow[t]{2}{*}{$K Z$} & -0.000 & -0.000 & -0.000 & -0.000 & -0.000 & -0.001 \\
\hline & $(0.001)$ & $(0.001)$ & $(0.001)$ & $(0.001)$ & $(0.001)$ & $(0.001)$ \\
\hline \multirow[t]{2}{*}{ Tobin's $Q$} & $0.058 * *$ & $0.057 * *$ & $0.057 *$ & $0.053^{*}$ & $0.049^{*}$ & -0.019 \\
\hline & $(0.028)$ & $(0.028)$ & $(0.029)$ & $(0.028)$ & $(0.028)$ & $(0.023)$ \\
\hline Firm FE & No & No & No & No & No & Yes \\
\hline Industry FE & Yes & Yes & Yes & Yes & Yes & No \\
\hline Year FE & Yes & Yes & Yes & Yes & Yes & Yes \\
\hline Obs. & 7,031 & 7,031 & 5,940 & 7,031 & 7,007 & 3,119 \\
\hline Adj. $R^{2}$ & 0.057 & 0.062 & 0.059 & 0.060 & 0.063 & 0.320 \\
\hline Panel B & \multicolumn{6}{|c|}{ Managerial Entrenchment } \\
\hline \multirow[t]{2}{*}{ Variable } & \multicolumn{3}{|c|}{ Independent Board } & \multicolumn{3}{|c|}{ Severance Agreement } \\
\hline & \multicolumn{3}{|c|}{$(1)$} & \multicolumn{3}{|c|}{ (2) } \\
\hline \multirow[t]{2}{*}{ PIO } & \multicolumn{3}{|c|}{$13.443 * * *$} & \multicolumn{3}{|c|}{$\begin{array}{c}-11.255^{*} \\
(6.494)\end{array}$} \\
\hline & \multicolumn{3}{|c|}{$(4.720)$} & \multicolumn{3}{|c|}{$(6.494)$} \\
\hline \multirow[t]{2}{*}{ LnAssets } & \multicolumn{3}{|c|}{-0.187} & \multicolumn{3}{|c|}{0.250} \\
\hline & \multicolumn{3}{|c|}{$(0.126)$} & \multicolumn{3}{|c|}{$(0.182)$} \\
\hline \multirow[t]{2}{*}{ LnAge } & \multirow{2}{*}{\multicolumn{3}{|c|}{$\begin{array}{c}-0.213^{* *} \\
(0.101)\end{array}$}} & & $0.323^{* *}$ & \\
\hline & & & & & $(0.143)$ & \\
\hline$R \& D$ & & 1.600 & & & 1.146 & \\
\hline & & $(0.71$ & & & $(0.935)$ & \\
\hline Capex & & -0.32 & & & 0.615 & \\
\hline & & $(0.59$ & & & $(0.759)$ & \\
\hline$P P E$ & & 0.294 & & & $-0.327^{*}$ & \\
\hline & & $(0.12$ & & & $(0.176)$ & \\
\hline Lev & & $1.440^{\circ}$ & & & -0.533 & \\
\hline & & $(0.33$ & & & $(0.477)$ & \\
\hline$R O A$ & & $\begin{array}{r}-2.193 \\
(0.89\end{array}$ & & & $\begin{array}{c}1.827 \\
(1217)\end{array}$ & \\
\hline$H H I$ & & -29.075 & & & 6.097 & \\
\hline & & $(10.5$ & & & (7.956) & \\
\hline$K Z$ & & -0.00 & & & 0.001 & \\
\hline & & $(0.00$ & & & $(0.002)$ & \\
\hline Tobin's $Q$ & & $0.113^{\prime}$ & & & -0.040 & \\
\hline & & $(0.03$ & & & $(0.053)$ & \\
\hline Industry FE & & Yes & & & Yes & \\
\hline Year FE & & Yes & & & Yes & \\
\hline Obs. & & 2,44 & & & 1,919 & \\
\hline Adj. $R^{2}$ & & 0.17 & & & 0.080 & \\
\hline
\end{tabular}




\begin{tabular}{|lcc|}
\hline \multicolumn{3}{|c|}{ Table 6. The Incentive Channel (Concluded) } \\
\hline \multicolumn{1}{|c|}{ Panel B } & \multicolumn{2}{c|}{ Managerial Entrenchment } \\
\hline Variable & Independent Board & Severance Agreement \\
\cline { 2 - 3 } & $(1)$ & $(2)$ \\
\hline HHI & $-29.075^{* * *}$ & 6.097 \\
& $(10.562)$ & $(7.956)$ \\
KZ & $-0.002^{*}$ & 0.001 \\
& $(0.001)$ & $(0.002)$ \\
Tobin's $Q$ & $0.113^{* * *}$ & -0.040 \\
& $(0.034)$ & $(0.053)$ \\
Industry FE & Yes & Yes \\
Year FE & Yes & Yes \\
Obs. & 2,443 & 1,919 \\
Adj. $R^{2}$ & 0.171 & 0.080 \\
& & \\
\hline
\end{tabular}

We report the results of probit models in Panel A of Table 6. In column (1), we only include $P I O$ as the key independent variable. In columns (2) - (5), we include the interaction terms between $P I O$ and a firm's financial and stock market performance measures. The coefficient estimates on $P I O$ are positive and significant in all columns, suggesting that higher passive institutional ownership leads to a higher probability of forced CEO turnover. On average, an increase in institutional ownership from the $25^{\text {th }}$ to the $75^{\text {th }}$ percentile of its distribution is associated with a 4.4 percent increase in the probability of forced CEO turnover in the following year. In columns (2)-(5), the coefficient estimates on the interaction terms are all positive and significant, suggesting greater CEO performance-turnover sensitivity after an increase in passive institutional ownership. As suggested in columns (2) and (3), if a firm's profitability decreases compared to the previous year or fails to beat the industry median, the values of the interaction terms are positive, which means that the firm's CEO is more likely to be replaced. Similarly, in columns (4) and (5), with an increase in PIO, a decline in a firm's stock returns or an underperformance in the market leads to a higher probability of forced CEO turnover, consistent with past studies (Jenter and Kanaan, 2015). It is easy to infer from the results that passive institutional investors will be unwilling to take the risk associated with explorative innovation as exploration fails easily and may lead to poor firm performance.

Next, we directly examine the risk-taking incentive scheme of top executives after the increase in passive institutional ownership. We construct the Vega of executives' compensation package. Vega is defined as an option's price sensitivity to changes in the volatility of the underlying asset. Argued by the previous literature (Liu and Mauer, 2011), the Vega of executive compensation captures the sensitivity of an executive's total income with respect to stock volatility. Hence, a higher Vega implies larger risk-taking incentives for managers. We replace the dependent variable with Vega and report the results in column (6) 
of Table 6 Panel A. The coefficient estimate on PIO is not statistically significant, suggesting that a manager's risk-taking incentives have not increased in response to increases in passive institutional ownership, which helps explain why managers undertake more exploitative instead of exploratory innovation.

To further explore the incentive and governance channel, we collect data on board independence from the ISS/RiskMetrics database. Our conjecture is that passive institutional ownership could increase a firm's board independence (Appel et al., 2016) and more independent boards reduce managerial entrenchment, which could create incentives for managers to pursue exploitative instead of exploratory innovation (Balsmeier et al., 2017). We define a board as an independent board if the majority of board members are classified as independent directors. Then, we use the board independence dummy as the dependent variable in the probit model and report the results in column (1) of Table 6 Panel B. Since independence is the foremost of the four fundamental principles to determine votes on director nominees in the benchmark policy recommendations of major proxy advisors (ISS, 2018), we expect an increase in board independence after more passive institutional investors become shareholders of a firm. ${ }^{8}$ The coefficient estimate on $P I O$ is positive and significant at the 1 percent level, suggesting that board independence improves after increases in passive institutional ownership. Specifically, if a firm's passive institutional holdings increase from the $25^{\text {th }}$ to the $75^{\text {th }}$ percentile of the distribution, its probability of having an independent board goes up by 20 percent. According to Balsmeier et al. (2017), more independent boards lead firms to engage more in exploitation of previously successful areas of expertise, because stronger board oversight increases both managerial effort and risk aversion.

Next, we focus a corporate governance practice that is crucial to managerial entrenchmentthe severance agreements, and explore how passive institutional investors alter them. A severance agreement refers to a contract that ensures a firm's top executives some income protection in the event of losing their positions. The most common type of severance agreement is golden parachute, which provides benefits to management and board members in the event of layoff, demotion, or resignation following a change in control (Bebchuk et al., 2009). We replace the dependent variable with Severance Agreement, a dummy that equals one if a firm has a contract which ensures executives some income protections in case of losing their positions and zero otherwise, and report the probit model estimation results in column (2) of Table 6 Panel B. The coefficient estimate on PIO is negative and significant, suggesting that firms are less likely to sign severance agreements as passive institutional ownership increases. In terms of economic significance, increasing a firm's institutional ownership from the $25^{\text {th }}$ to the $75^{\text {th }}$ percentile of its distribution decreases the probability of implementing severance contracts by 10 percent. Without severance agreements, managers are less safeguarded against innovation failures, and are thus more attracted to conservative exploitation.

The above observed changes in corporate governance after an increase in passive institutional ownership, including the improvement in board independence and the decrease in severance agreements, could serve to weaken managerial entrenchment. As a consequence, managers

\footnotetext{
${ }^{8}$ Institutional Shareholder Services, 2018. United States Proxy Voting Guidelines. Available at https://www.issgovernance.com/file/policy/2018/americas/US-Voting-Guidelines.pdf
} 
are exposed to higher replacement probabilities, which increase their risk aversion and incentives to undertake exploitative instead of exploratory innovation.

\section{Robustness CHecks}

In this section, we perform a variety of additional tests to check the robustness of our main results. Specifically, we repeat our tests with alternative bandwidths, different polynomial orders, alternative measures of Russell rankings, and alternative definitions of passive institutional ownership. We also undertake falsification tests to ensure that our results are unlikely spurious or driven by chance. To save space, we only report the robustness checks with the number of patents as the dependent variable. ${ }^{9}$

\section{A. Alternative Bandwidths}

We first examine whether our main results are robust to alternative bandwidths. The choice of bandwidth reflects a tradeoff between precision and bias. Using a wider bandwidth that includes more observations surrounding the threshold could generate more precise estimates. It could, however, bias the estimates as the linear specification is less likely to be accurate. The reverse occurs if we use a narrower bandwidth (Bradley et al., 2017). Hence, we perform the first robustness test to ensure that our results are not sensitive to alternative bandwidths. Specifically, we repeat our baseline regressions for different bandwidths around the threshold and report the results in Table 7 Panel A. The regression results remain robust with smaller $( \pm 100, \pm 200)$, larger $( \pm 500)$ bandwidths, and the optimal algorithm-selected bandwidth proposed by Imbens and Kalyanaraman (2012).

\footnotetext{
${ }^{9}$ Our results are consistent with other innovation input and output variables under each robustness check and the falsification test.
} 


\section{Table 7. Robustness Checks}

Table 7 provides results of robustness checks. Panel A uses alternative bandwidths $( \pm 100, \pm 200$, \pm 500 , and the optimal bandwidths). Panel B uses different polynomial orders ( $\kappa=1,2$, and 3$)$ in the two-stage least squares estimation. Panel $\mathrm{C}$ uses the end-of-June market capitalization ranking and alternative definition of institutional ownership. Panel D reports the results of falsification tests using placebo thresholds of ranking 500, 750, 1,500, and 1,750.

\begin{tabular}{|c|c|c|c|c|}
\hline \multirow{2}{*}{$\frac{\text { Panel A }}{\text { Variable }}$} & \multicolumn{4}{|c|}{ Alternative Bandwidths } \\
\hline & Bandwidth \pm 100 & Bandwidth \pm 200 & Bandwidth \pm 500 & Optimal \\
\hline & LnPat & LnPat & LnPat & LnPat \\
\hline & $(1)$ & (3) & (4) & $(2)$ \\
\hline \multirow[t]{2}{*}{$\mathrm{PIO}$} & $5.160 * *$ & $5.198 * * *$ & $4.307 * * *$ & $7.087 * * *$ \\
\hline & $(2.498)$ & $(1.853)$ & (1.648) & $(2.269)$ \\
\hline \multirow[t]{2}{*}{ LnAssets } & 0.040 & -0.041 & -0.029 & -0.105 \\
\hline & $(0.063)$ & $(0.066)$ & $(0.061)$ & $(0.075)$ \\
\hline \multirow[t]{2}{*}{ LnAge } & $-0.148 * *$ & $-0.151 * * *$ & $-0.115 * *$ & $-0.176 * * *$ \\
\hline & $(0.072)$ & $(0.058)$ & $(0.049)$ & $(0.067)$ \\
\hline \multirow[t]{2}{*}{$R \& D$} & $5.369 * * *$ & $4.038 * *$ & $4.955 * * *$ & $3.111 *$ \\
\hline & $(0.991)$ & $(1.624)$ & $(1.021)$ & $(1.779)$ \\
\hline \multirow[t]{2}{*}{ Capex } & 0.443 & 0.340 & 0.190 & $0.630 *$ \\
\hline & $(0.321)$ & $(0.261)$ & $(0.206)$ & $(0.331)$ \\
\hline \multirow[t]{2}{*}{$P P E$} & -0.221 & -0.037 & 0.064 & -0.135 \\
\hline & $(0.164)$ & $(0.101)$ & $(0.071)$ & $(0.115)$ \\
\hline \multirow[t]{2}{*}{ Lev } & -0.064 & 0.118 & 0.030 & 0.249 \\
\hline & $(0.192)$ & $(0.183)$ & $(0.154)$ & $(0.193)$ \\
\hline \multirow[t]{2}{*}{$R O A$} & -0.625 & $-0.967 * *$ & $-0.905 * *$ & $-1.663 * *$ \\
\hline & $(0.602)$ & $(0.480)$ & $(0.394)$ & $(0.647)$ \\
\hline \multirow[t]{2}{*}{$H H I$} & -1.136 & -1.169 & $-3.166^{*}$ & -1.816 \\
\hline & $(3.145)$ & $(2.324)$ & $(1.645)$ & $(2.937)$ \\
\hline \multirow[t]{2}{*}{$K Z$} & -0.000 & -0.000 & -0.000 & -0.000 \\
\hline & $(0.000)$ & $(0.000)$ & $(0.000)$ & $(0.000)$ \\
\hline \multirow[t]{2}{*}{ Tobins $Q$} & 0.009 & 0.025 & 0.008 & 0.027 \\
\hline & $(0.021)$ & $(0.017)$ & $(0.010)$ & $(0.019)$ \\
\hline Firm FE & Yes & Yes & Yes & Yes \\
\hline Year FE & Yes & Yes & Yes & Yes \\
\hline Obs. & 2,284 & 4,623 & 11,925 & 3,054 \\
\hline Adj. $R^{2}$ & 0.290 & 0.290 & 0.309 & 0.276 \\
\hline
\end{tabular}


Table 7. Robustness Checks (Continued)

\begin{tabular}{|c|c|c|c|}
\hline \multirow{4}{*}{$\begin{array}{l}\text { Panel B } \\
\text { Variable }\end{array}$} & \multicolumn{3}{|c|}{ Different Polynomial Orders } \\
\hline & $\kappa=1$ & $\kappa=2$ & $\kappa=3$ \\
\hline & LnPat & LnPat & LnPat \\
\hline & $(1)$ & $(2)$ & $(3)$ \\
\hline \multirow[t]{2}{*}{ PIO } & $4.336 * *$ & $3.787 * *$ & $4.679 * *$ \\
\hline & $(2.121)$ & $(1.714)$ & 1.856 \\
\hline \multirow{2}{*}{ LnAssets } & -0.020 & -0.008 & -0.030 \\
\hline & $(0.068)$ & $(0.061)$ & $(0.062)$ \\
\hline \multirow[t]{2}{*}{ LnAge } & $-0.112 * *$ & $-0.101 * *$ & $-0.118 * *$ \\
\hline & $(0.056)$ & $(0.050)$ & $(0.054)$ \\
\hline \multirow[t]{2}{*}{$R \& D$} & $4.672 * * *$ & $4.695 * * *$ & $4.659 * * *$ \\
\hline & $(1.342)$ & $(1.340)$ & $(1.335)$ \\
\hline \multirow[t]{2}{*}{ Capex } & 0.288 & 0.264 & 0.307 \\
\hline & $(0.249)$ & $(0.245)$ & $(0.253)$ \\
\hline \multirow[t]{2}{*}{$P P E$} & 0.030 & 0.033 & 0.032 \\
\hline & $(0.083)$ & $(0.083)$ & $(0.083)$ \\
\hline \multirow[t]{2}{*}{$L e v$} & 0.001 & -0.033 & 0.026 \\
\hline & $(0.186)$ & $(0.176)$ & $(0.183)$ \\
\hline \multirow[t]{2}{*}{$R O A$} & $-0.833 *$ & $-0.735^{*}$ & $-0.896 * *$ \\
\hline & $(0.484)$ & $(0.421)$ & $(0.437)$ \\
\hline \multirow[t]{2}{*}{$H H I$} & -2.662 & -2.560 & -2.763 \\
\hline & (1.895) & (1.889) & (1.907) \\
\hline \multirow[t]{2}{*}{$K Z$} & 0.000 & 0.001 & 0.000 \\
\hline & $(0.001)$ & $(0.001)$ & $(0.001)$ \\
\hline \multirow[t]{2}{*}{ TobinsQ } & 0.017 & 0.014 & 0.018 \\
\hline & $(0.016)$ & $(0.015)$ & $(0.015)$ \\
\hline Firm FE & Yes & Yes & Yes \\
\hline Year FE & Yes & Yes & Yes \\
\hline Obs. & 7,035 & 7,035 & 7,035 \\
\hline Adj. $R^{2}$ & 0.292 & 0.292 & 0.292 \\
\hline
\end{tabular}




\begin{tabular}{|c|c|c|c|c|}
\hline \multicolumn{5}{|c|}{ Table 7. Robustness Checks (Continued) } \\
\hline \multirow{3}{*}{$\begin{array}{l}\text { Panel C } \\
\text { Variable }\end{array}$} & \multicolumn{2}{|c|}{ End-of-June Ranking } & \multicolumn{2}{|c|}{ Alternative Definitions of PIO } \\
\hline & LnPat & LnCite & LnPat & LnCite \\
\hline & $(1)$ & $(2)$ & $(3)$ & $(4)$ \\
\hline \multirow[t]{2}{*}{$\mathrm{PIO}$} & $1.407^{*}$ & $2.594 * *$ & $2.706^{* *}$ & $3.123 * *$ \\
\hline & $(0.839)$ & $(1.036)$ & $(1.324)$ & $(1.444)$ \\
\hline \multirow[t]{2}{*}{ LnAssets } & $0.124 * * *$ & $0.093 * *$ & 0.053 & 0.037 \\
\hline & $(0.035)$ & $(0.042)$ & $(0.045)$ & $(0.046)$ \\
\hline \multirow[t]{2}{*}{ LnAge } & -0.042 & $-0.121 * *$ & -0.054 & $-0.073 *$ \\
\hline & $(0.039)$ & $(0.047)$ & $(0.041)$ & $(0.040)$ \\
\hline \multirow[t]{2}{*}{$R \& D$} & $5.016^{* * *}$ & $5.457 * * *$ & $4.353 * * *$ & $3.439 * * *$ \\
\hline & $(0.660)$ & $(0.785)$ & $(1.379)$ & $(1.250)$ \\
\hline \multirow[t]{2}{*}{ Capex } & 0.096 & 0.322 & -0.020 & 0.134 \\
\hline & $(0.225)$ & $(0.279)$ & $(0.236)$ & $(0.272)$ \\
\hline \multirow[t]{2}{*}{$P P E$} & 0.076 & -0.021 & 0.133 & 0.016 \\
\hline & $(0.074)$ & $(0.097)$ & $(0.092)$ & $(0.095)$ \\
\hline \multirow[t]{2}{*}{ Lev } & -0.118 & $-0.308 * *$ & -0.173 & $-0.299 * *$ \\
\hline & $(0.128)$ & $(0.152)$ & $(0.142)$ & $(0.145)$ \\
\hline \multirow[t]{2}{*}{$R O A$} & -0.143 & -0.337 & -0.497 & -0.462 \\
\hline & $(0.254)$ & $(0.318)$ & $(0.362)$ & $(0.376)$ \\
\hline \multirow[t]{2}{*}{$H H I$} & $-3.349 *$ & $-13.231 * * *$ & -2.797 & $-10.438 * * *$ \\
\hline & $(1.841)$ & $(2.546)$ & $(1.911)$ & $(2.137)$ \\
\hline \multirow[t]{2}{*}{$K Z$} & $0.002 * *$ & 0.002 & 0.000 & 0.001 \\
\hline & $(0.001)$ & $(0.001)$ & $(0.001)$ & $(0.002)$ \\
\hline \multirow[t]{2}{*}{ TobinsQ } & 0.013 & $0.041 * *$ & 0.011 & 0.027 \\
\hline & $(0.013)$ & $(0.018)$ & $(0.014)$ & $(0.016)$ \\
\hline Firm FE & Yes & Yes & Yes & Yes \\
\hline Year FE & Yes & Yes & Yes & Yes \\
\hline Obs. & 7,093 & 7,093 & 7,035 & 7,035 \\
\hline Adj. $R^{2}$ & 0.286 & 0.265 & 0.292 & 0.269 \\
\hline
\end{tabular}




\begin{tabular}{|c|c|c|c|c|}
\hline \multicolumn{5}{|c|}{ Table 7. Robustness Checks (Concluded) } \\
\hline Panel D & \multicolumn{4}{|c|}{ Falsification Tests } \\
\hline \multirow{3}{*}{ Variable } & Cutoff $=500$ & Cutoff $=750$ & Cutoff $=1500$ & Cutoff $=1750$ \\
\hline & LnPat & LnPat & LnPat & LnPat \\
\hline & & $(2)$ & (3) & (4) \\
\hline \multirow[t]{2}{*}{$\mathrm{PIO}$} & -1.724 & -0.713 & -9.004 & 43.525 \\
\hline & $(3.017)$ & 8.183 & 17.759 & 46.202 \\
\hline \multirow[t]{2}{*}{ LnAssets } & $0.141 *$ & $0.446 * * *$ & 0.421 & -1.416 \\
\hline & $(0.082)$ & $(0.117)$ & $(0.660)$ & $(1.605)$ \\
\hline \multirow[t]{2}{*}{ LnAge } & 0.147 & 0.166 & 0.079 & -0.654 \\
\hline & $(0.097)$ & $(0.187)$ & $(0.242)$ & $(0.670)$ \\
\hline \multirow[t]{2}{*}{$R \& D$} & $11.256 * * *$ & $14.052 * * *$ & $3.873 * * *$ & 1.858 \\
\hline & $(1.249)$ & $(1.753)$ & $(0.924)$ & (1.769) \\
\hline \multirow[t]{2}{*}{ Capex } & -0.738 & -1.040 & -0.180 & 1.052 \\
\hline & $(0.635)$ & $(1.837)$ & $(0.596)$ & $(1.027)$ \\
\hline \multirow[t]{2}{*}{$P P E$} & 0.158 & 0.132 & 0.030 & 0.008 \\
\hline & $(0.150)$ & $(0.356)$ & $(0.067)$ & $(0.060)$ \\
\hline \multirow[t]{2}{*}{ Lev } & -0.272 & $-0.495^{*}$ & -1.168 & 4.966 \\
\hline & $(0.231)$ & $(0.291)$ & $(1.796)$ & $(5.485)$ \\
\hline \multirow[t]{2}{*}{$R O A$} & -0.731 & -0.203 & 1.310 & -4.486 \\
\hline & $(0.541)$ & $(0.695)$ & $(2.692)$ & $(4.994)$ \\
\hline \multirow[t]{2}{*}{$H H I$} & 0.002 & 0.001 & 0.001 & -0.004 \\
\hline & $(0.001)$ & $(0.005)$ & $(0.002)$ & $(0.005)$ \\
\hline \multirow[t]{2}{*}{$K Z$} & 0.001 & 0.002 & 0.005 & -0.017 \\
\hline & $(0.002)$ & $(0.004)$ & $(0.008)$ & $(0.018)$ \\
\hline \multirow[t]{2}{*}{ TobinsQ } & $-0.033^{*}$ & 0.019 & -0.026 & 0.067 \\
\hline & $(0.019)$ & $(0.053)$ & $(0.024)$ & $(0.087)$ \\
\hline Firm FE & Yes & Yes & Yes & Yes \\
\hline Year FE & Yes & Yes & Yes & Yes \\
\hline Obs. & 6,881 & 5,555 & 7,579 & 7,836 \\
\hline$A d j . R^{2}$ & 0.408 & 0.502 & 0.247 & 0.234 \\
\hline
\end{tabular}

\section{B. Alternative Polynomial Orders}

In our baseline regressions, we use a linear specification in index rankings on either side of the Russell 1000/2000 threshold. To check the robustness of the linear specification, we allow the relation between the forcing variable and the outcome to be nonlinear and repeat the tests with different polynomial orders, specifically the quadratic and cubic orders. Intuitively, rectangular and triangular kernels help generate a weighted average of outcomes 
for treated observations on one side of the discontinuity and for controlled observations on the other side. We report the results in Table 7 Panel B. The coefficient estimates are consistent with our main findings, suggesting that our main results are not sensitive to alternative polynomial orders.

\section{Alternative Russell Rankings}

Russell uses a float adjustment approach to construct index weights and rankings at the end of June, placing all of the most illiquid stocks at the bottom of the Russell 1000 index. Thus, the ranking of firms on the reconstitution day (the end of May) is not the same as that on the announcement day (the end of June). This adjustment is subtle but important, because our assumption of local randomization depends on firms being comparable around the threshold. To address this concern, we restore the end-of-May market capitalization, which predicts a firm's index assignment, based on the data from CRSP and Compustat. To ensure the robustness of our main results, we repeat the test using the end-of-June actual index rankings provided by the FTSE Russell. The coefficient estimates on PIO in columns (1) and (2) of Table 7 Panel $\mathrm{C}$ are positive and significant, confirming that our main results do not change qualitatively and quantitatively if we use alternative Russell rankings.

\section{Alternative Institutional Ownership Definitions}

In this paper, we define passive institutional investors as quasi-indexers using Bushee (2001)'s definition. It is important to note that both actively managed transient investors and quasi-indexers are likely to be compensated based on a benchmark. Thus, even if transient owners take active bets on certain stocks, they are still likely to hold sizable positions in firms with large index weights in the benchmark. To check whether our main results are robust to alternative definitions of passive institutional investors, we include both quasiindexers and transient investors in the calculation of passive institutional holdings and report the results in columns (3) and (4) of Panel C. The coefficient estimates on PIO are positive and significant, suggesting that our main results are robust to alternative definitions of passive institutional investors.

\section{E. Placebo Thresholds}

We perform a series of falsification tests to check if we are still able to observe the discontinuity in innovation measures at artificially chosen thresholds that are different from the true Russell 1000/2000 threshold. If we do, the regression discontinuity results are likely to be spurious and the effect of passive institutional investors on innovation is likely driven by chance. We use several placebo thresholds $(500,750,1,500$ and 1,750) in the Russell 3000 index, assuming that they are the thresholds that determine index assignment and repeat our baseline estimations. We report the results in Table 7 Panel D. The coefficient estimates on passive institutional ownership are all statistically insignificant, suggesting that the treatment effects of passive institutional ownership due to the index reconstitution on firms' innovation outcomes are absent at these artificially assigned thresholds. The set of falsification tests helps us ensure that the effect of passive institutional ownership on innovation documented in our main analyses is unlikely driven by chance, and hence our baseline results are unlikely spurious. 
To summarize, our baseline results are robust to alternative bandwidths, alternative polynomial orders, alternative measures of Russell rankings, and alternative definitions of passive institutional ownership. The falsification tests also ensure that our results are unlikely to be spurious.

\section{CONCLUSION}

In this paper, we have differentiated the effects of passive institutional investors on firms' innovation activities and innovation strategies and explored plausible underlying economic channels. Relying on plausibly exogenous variation in passive institutional ownership generated by the Russell 1000/2000 index reconstitution, we find that, with higher levels of passive institutional ownership, while firms' observable and countable innovation input and output increase, they focus more on the exploitation of existing knowledge instead of exploring new technology. Enhanced monitoring by passive institutional investors through active votes could explain their positive effects on firms' innovation activities. Increased risk aversion on the part of passive institutional investors appears the underlying force that alters firms' innovation strategies of shifting to incremental innovation. Our paper uncovers a subtle relation between institutional investors and corporate innovation, which is largely ignored by the earlier studies, and has important policy implications.

Is the observed shift to exploitation good or bad for overall firm performance? As corporate represents an important force for technological innovation, will the shift affect aggregate productivity? Should corporate governance guidelines be revisited to reflect the ongoing rise of passive investors? Finally, as the passive investing industry becomes increasingly dominated by giant institutional investors including Blackrock, Vanguard and State Street, will a new framework be required that combines better corporate law, financial regulation and structural reforms? These are important topics for future research and policy-making. 


\section{REFERENCES}

Acharya V., Baghai, R., Subramanian, K., 2013. Labor laws and innovation. Journal of Law and Economics 56, 997-1037.

Aghion, P., Van Reenen J., Zingales L., 2013. Innovation and institutional ownership. American Economic Review 103, 277-304.

Appel, I., Gormley, T., Keim, D., 2016. Passive investors, not passive owners. Journal of Financial Economics 121(1), 111-141.

Argente, D., Baslandze, S., Hanley, D., Moreira, S., 2019. Patents to products: Innovation, product creation, and firm growth. Unpublished Working Paper.

Balsmeier, B., Fleming, L., Manso, G., 2017. Independent boards and innovation. Journal of Financial Economics 123, 536-557.

Bebchuk, L.A., Cohen, A., Ferrell, A., 2009. What matters in corporate governance?. Review of Financial Studies 22(2), 783-827.

Benartzi, S., Thaler, R.H., 1995. Myopic loss aversion and the equity premium puzzle. Quarterly Journal of Economics 110(1), 73-92.

Bertrand, M., Mullainathan, S., 2003. Enjoying the quiet life? Corporate governance and managerial preferences. Journal of Political Economy 111(5), 1043-75.

Bethel, J., Gillan, S., 2002. The impact of the institutional and regulatory environment on shareholder voting. Financial Management 31(4), 29-54.

Blanding, M., 2017. Vanguard, Trian and the problem with "passive” index funds.

Blundell, R., Griffith, R., Van Reenen, J., 1999. Market share, market value and innovation in a panel of British manufacturing firms. Review of Economic Studies 66(3), 529-554.

Boone, A., White, J., 2015. The effect of institutional ownership on firm transparency and information production. Journal of Financial Economics 117, 508-533.

Bradley, D., Kim, I., Tian, X., 2017. Do unions affect innovation? Management Science 63(7), 2049-2395.

Bushee, B. J., 2001. Do institutional investors prefer near-term earnings over long-run value? Contemporary Accounting Research 18(2), 207-246.

Brav, A., Jiang, W., Ma, S., and Tian, X., 2018. How does hedge fund activism reshape corporate innovation? Journal of Financial Economics, 130(2), 237-264.

Chemmanur, T., Loutskina, E., and Tian, X., 2014. Corporate venture capital, value creation, and innovation. Review of Financial Studies 27(8), 2434-2473.

Cornaggia, J., Mao, Y., Tian, X, and Wolfe, B., 2015. Does banking competition affect innovation? Journal of Financial Economics 115, 189-209. 
Crane, A., Michenaud, S., Weston, J., 2016. The effect of institutional ownership on payout policy: Evidence from index thresholds. Review of Financial Studies 29(6), 1377-1408.

Del Guercio, D., 1996. The distorting effect of the prudent-man laws on institutional equity investments. Journal of Financial Economics 40(1), 31-62.

Fang, V., Tian, X., and Tice, S., 2014. Does stock liquidity enhance or impede firm innovation? Journal of Finance 69, 2085-2125.

Fich, E., Harford, J., Tran, A., 2015. Motivated monitors: the importance of institutional investors' portfolio weights. Journal of Financial Economics 118, 21-48.

Fisch, J.E., Hamdani, A., Solomon. D., S., 2019. The new titans of wall street: A theoretical framework of passive investors. University of Pennsylvania Law Review 168, 17-72.

Gillan, S. L., Starks, L. T., 2003. Corporate governance, corporate ownership, and the role of institutional investors: A global perspective. Journal of Applied Finance 13, 4-22.

Griliches, Z., 1990. Patent statistics as economic indicators: A survey. Journal of Economic Literature 28, 1661-1707.

Gu, Y., Mao, C., and Tian. X., 2017. Bank interventions and firm innovation: Evidence from debt covenant violations. Journal of Law and Economics 60(4), 637-671.

Hall, B.H., Jaffe A., Trajtenberg, M., 2001. The NBER patent citation data file: Lessons, insights and methodological tools. NBER Working Paper.

Hall, B.H., Jaffe, A., Trajtenberg, M., 2005. Market value and patent citations. RAND Journal of Economics 36(1), 16-38.

Harris, M., Raviv, A., 1978. Some results on incentive contracts with application to education and employment, health insurance, and law enforcement. American Economic Review 68(1), 20-30.

He, J., Tian, X., 2013. The dark side of analyst coverage: The case of innovation. Journal of Financial Economics 109, 856-878.

He, J., Tian, X., 2018. Finance and corporate innovation: A survey. Asia-Pacific Journal of Financial Studies 47, 165-212.

He, J., Tian, X., 2020. Institutions and innovation: A review of recent literature, Annual Review of Financial Economics 12, 377-398.

Hirshleifer, D., Hsu, P.H., Li, D., 2018. Innovative originality, profitability, and stock returns. Review of Financial Studies 31, 2553-2605.

Hirshleifer, D., Low, A., Teoh, S.H., 2012. Are overconfident CEOs better innovators? Journal of Finance 72, 1457-1498.

Holmstrom, B., 1989. Agency costs and innovation. Journal of Economic Behavior and Organization 12, 305-327. 
Holmstrom, B., 1999. Managerial incentive problems: A dynamic perspective. Review of Economic Studies 66(1), 169-182.

Hsu, P.H., Tian, X., Xu, Y., 2014. Financial development and innovation: Cross-country evidence. Journal of Financial Economics 112(1), 116-135.

Imbens, G., Kalyanaraman, K., 2012. Optimal bandwidth choice for the regression discontinuity estimator. Review of Economic Studies 79(3), 933-959.

Jaffe, A., 1989. Real effects of academic research. American Economic Review 79(5), 957970.

Jensen, M.C., Meckling, W.H., 1976. Theory of the firm: Managerial behavior, agency costs and ownership structure. Journal of Financial Economics 3, 305-360.

Jenter, D., Kanaan, F., 2015. CEO turnover and relative performance evaluation. Journal of Finance 70(5). 2155-2183.

Kahan, M., Rock, E.B., 2007. Hedge funds in corporate governance and corporate control. University of Pennsylvania Law Review 155, 1021.

Kahn, C., Winton A., 1998. Ownership structure, speculation, and shareholder intervention. Journal of Finance 53(1), 99-129.

Kaplan, S.N., Zingales, L., 1997. Do investment-cash flow sensitivities provide useful measures of financing constraints?. Quarterly Journal of Economics 112(1), 169-215.

Lanjouw, J.O., Schankerman, M., 2004. Patent quality and research productivity: Measuring innovation with multiple indicators. Economic Journal 114(495), 441-465.

Lee, D.S., Lemieux, T., 2010. Regression discontinuity designs in economics. Journal of Economic Literature 48(2), 281-355.

Lerner, J., Sorensen, M., Stromberg, P., 2011. Private equity and long-run investment: The case of innovation. Journal of Finance 66, 445-477.

Levine, R., Lin, C., Wei, L., 2017. Insider trading and innovation. Journal of Law and Economics 60(4), 749-800.

Lin, C., Liu, S., Manso, G., 2019. Shareholder litigation and corporate innovation. Working paper, Hong Kong University.

Liu, Y., Mauer, D.C., 2011. Corporate cash holdings and CEO compensation incentives, Journal of Financial Economics 102(1), 183-198.

Liu, Y., Shen, Y., Wang, J., Wang, Q., 2020. Passive institutional investors and corporate innovation. Working paper, Southwestern University of Finance and Economics.

Luong, H., Moshirian, F., Nguyen, L., Tian, X., Zhang, B., 2017. How do foreign institutional investors enhance firm innovation? Journal of Financial and Quantitative Analysis 52, 1449-1490. 
Imbens, G., Kalyanaraman, K., 2012. Optimal bandwidth choice for the regression discontinuity estimator. Review of Economic Studies 79(3), 933-959.

McCrary, J., 2008. Manipulation of the assignment variable in the regression discontinuity design: A density test. Journal of Econometrics 142, 698-714.

Manso, G., 2011. Motivating innovation. Journal of Finance 66(5), 1823-1860.

Matutes, C., Regibeau, P., Rockett, K., 1996. Optimal patent design and the Diffusion of Innovations. RAND Journal of Economics 27(1), 60-83.

Moshirian, F., Tian, X., Zhang, B., Zhang, W., 2020. Financial liberalization and innovation. Journal of Financial Economics, forthcoming.

Mullins, W., 2014. The governance impact of index funds: evidence from a regression discontinuity. Unpublished Working Paper, University of Maryland.

Porter, M. E., 1985. The Competitive Advantage: Creating and Sustaining Superior Performance, NY: Free Press.

Sariol, A.M., Abebe, M.A., 2017. The influence of CEO power on explorative and exploitative organizational innovation. Journal of Business Research 73, 38-45.

Schochet, P.Z., 2008. Technical methods report: statistical power for regression discontinuity designs in education evaluations. NCEE 2008-4026.

Seru, A., 2014. Firm boundaries matter: Evidence from conglomerates and R\&D activity. Journal of Financial Economics 111, 381-405.

Shleifer, A., Vishny, R.W., 1986. Large shareholders and corporate control. Journal of Political Economy 94(3), 461-488.

Sias, R.W., 1996. Volatility and the institutional investor. Financial Analysts Journal 52(2), 13-20.

Solow, R., 1957. Technical change and the aggregate production function. Review of Economics and Statistics 39, 312-320.

Tian, X., Wang T., 2014. Tolerance for failure and corporate innovation. Review of Financial Studies 27, 211-255.

Trajtenberg, M, Jaffe, A., Henderson, R., 1997. University versus corporate patents: A window on the basicness of inventions. Economics of Innovation and New Technology 5(1), 1950 . 


\section{APPENDIX}

\section{Definition and Source of Variables}

\begin{tabular}{|c|c|c|}
\hline Variable & Definition & Source \\
\hline LnPat & $\begin{array}{l}\text { Natural logarithm of one plus the total number } \\
\text { of patents filed (and eventually granted) by a } \\
\text { firm in a year }\end{array}$ & $\begin{array}{c}\text { NBER Patent Citation } \\
\text { Database }\end{array}$ \\
\hline LnCite & $\begin{array}{l}\text { Natural logarithm of one plus the total number } \\
\text { of citations made to a firm's patents scaled by } \\
\text { the total number of patents }\end{array}$ & $\begin{array}{c}\text { NBER Patent Citation } \\
\text { Database }\end{array}$ \\
\hline ClaimNo & $\begin{array}{l}\text { Natural logarithm of one plus the total number } \\
\text { of claims associated with a firm's patents } \\
\text { scaled by the total number of patents }\end{array}$ & $\begin{array}{l}\text { USPTO Patent Claims } \\
\text { Research Dataset }\end{array}$ \\
\hline ClaimLength & $\begin{array}{l}\text { Natural logarithm of one plus the total word } \\
\text { counts associated with a firm's patent claims } \\
\text { scaled by the total number of patents }\end{array}$ & $\begin{array}{l}\text { USPTO Patent Claims } \\
\text { Research Dataset }\end{array}$ \\
\hline Breakthrough & $\begin{array}{l}\text { Natural logarithm of one plus the number of } \\
\text { patents that fall in the top } 10 \text { percent } \\
\text { percentile of the citation distribution within } \\
\text { technology class and application year }\end{array}$ & $\begin{array}{c}\text { NBER Patent Citation } \\
\text { Database }\end{array}$ \\
\hline Failure & $\begin{array}{l}\text { Natural logarithm of one plus the number of } \\
\text { patents that receive no citations }\end{array}$ & $\begin{array}{c}\text { NBER Patent Citation } \\
\text { Database }\end{array}$ \\
\hline Incremental & $\begin{array}{l}\text { Natural logarithm of one plus the number of } \\
\text { patents that are neither breakthroughs nor } \\
\text { failures }\end{array}$ & $\begin{array}{c}\text { NBER Patent Citation } \\
\text { Database }\end{array}$ \\
\hline NewField & $\begin{array}{l}\text { Natural logarithm of one plus the number of } \\
\text { patents that are filed in technology classes } \\
\text { new to the firm }\end{array}$ & $\begin{array}{c}\text { NBER Patent Citation } \\
\text { Database }\end{array}$ \\
\hline Originality & $\begin{array}{l}\text { Dispersion of cited patents over technological } \\
\text { classes }\end{array}$ & $\begin{array}{c}\text { NBER Patent Citation } \\
\text { Database }\end{array}$ \\
\hline Generality & $\begin{array}{l}\text { Dispersion of citing patents over } \\
\text { technological classes }\end{array}$ & $\begin{array}{c}\text { NBER Patent Citation } \\
\text { Database }\end{array}$ \\
\hline Product & $\begin{array}{l}\text { Natural logarithm of one plus the total number } \\
\text { of new products }\end{array}$ & Capital IQ \\
\hline$I O$ & $\begin{array}{l}\text { Percentage of common shares held by all } \\
\text { types of institutional investors }\end{array}$ & $\begin{array}{l}\text { Institutional 13(f) } \\
\text { Holdings }\end{array}$ \\
\hline $\mathrm{PIO}$ & $\begin{array}{l}\text { Percentage of common shares held by passive } \\
\text { institutional investors or quasi-indexers }\end{array}$ & Brian Bushee website \\
\hline TIO & $\begin{array}{l}\text { Percentage of common shares held by } \\
\text { transient institutional investors }\end{array}$ & Brian Bushee website \\
\hline $\mathrm{DIO}$ & $\begin{array}{l}\text { Percentage of common shares held by } \\
\text { dedicated institutional investors }\end{array}$ & Brian Bushee website \\
\hline Size & Natural logarithm of total assets of a firm & Compustat \\
\hline Age & Number of years since the firm's IPO & Compustat \\
\hline
\end{tabular}




\begin{tabular}{|c|c|c|}
\hline Variable & Definition & Source \\
\hline$R \& D$ & $\begin{array}{l}\text { Research and development expenses scaled by } \\
\text { total assets }\end{array}$ & Compustat \\
\hline Capex & Capital expenditure scaled by total assets & Compustat \\
\hline$P P E$ & $\begin{array}{l}\text { Net property, plant, and equipment scaled by } \\
\text { total assets }\end{array}$ & Compustat \\
\hline Lev & Total debt over total assets & Compustat \\
\hline$R O A$ & $\begin{array}{l}\text { Operating income before depreciation divided } \\
\text { by total assets }\end{array}$ & Compustat \\
\hline$H H I$ & $\begin{array}{l}\text { Herfindal-Hirschman index constructed based } \\
\text { on two-digit Standard Industrial Classification } \\
\text { (SIC) number }\end{array}$ & Compustat \\
\hline TobinsQ & $\begin{array}{l}\text { Market value of equity plus book value of } \\
\text { assets minus book value of equity minus } \\
\text { balance sheet deferred taxes scaled by total } \\
\text { assets }\end{array}$ & Compustat \\
\hline$K Z$ & $\begin{array}{l}-1.002 \times \text { cash flow [(income before } \\
\text { extraordinary items }+ \text { depreciation and } \\
\text { amortization)/lagged net property, plant, and } \\
\text { equipment] }+0.283 \times \text { tobinsq [market value } \\
\text { of equity }+ \text { book value of total assets }- \text { book } \\
\text { value of equity }- \text { balance sheet deferred tax] }+ \\
3.139 \times \text { leverage [total debt/total assets] }- \\
39.368 \times \text { dividends [(preferred dividends }+ \\
\text { common dividends)/lagged net property, } \\
\text { plant, and equipment] }-1.315 \times \text { cash holdings } \\
{[(\text { cash and short-term investment) } /(\text { lagged net }} \\
\text { property, plant, and equipment)] }\end{array}$ & Compustat \\
\hline Vote Participation & $\begin{array}{l}\text { Number of meetings where passive funds cast } \\
\text { a vote over total number of meetings }\end{array}$ & ISS \\
\hline Vote For Percentage & $\begin{array}{l}\text { Number of meetings where passive funds cast } \\
\text { a "For" vote over total number of meetings }\end{array}$ & ISS \\
\hline $\begin{array}{l}\text { Vote Against } \\
\text { Percentage }\end{array}$ & $\begin{array}{l}\text { Number of meetings where passive funds cast } \\
\text { an "Against" vote over total number of } \\
\text { meetings }\end{array}$ & ISS \\
\hline $\begin{array}{l}\text { Disagree with } \\
\text { Management }\end{array}$ & $\begin{array}{l}\text { Number of meetings in which passive funds' } \\
\text { vote is different from management vote } \\
\text { recommendation over total number of } \\
\text { meetings }\end{array}$ & ISS \\
\hline CEO Turnover & $\begin{array}{l}\text { A dummy variable that equals one when there } \\
\text { is forced CEO change in a year, and zero } \\
\text { otherwise }\end{array}$ & Execucomp \\
\hline$\triangle R O A$ & $\begin{array}{l}\text { A dummy variable that equals one if the } \\
\text { firm's return on assets in the current year is } \\
\text { lower than that in the previous year, and zero } \\
\text { otherwise }\end{array}$ & Compustat \\
\hline
\end{tabular}




\begin{tabular}{|c|c|c|}
\hline Variable & Definition & Source \\
\hline IndROA & $\begin{array}{l}\text { A dummy variable that equals one if the } \\
\text { firm's return on assets is lower than the } \\
\text { industry median, and zero otherwise }\end{array}$ & Compustat \\
\hline$\Delta R e t$ & $\begin{array}{l}\text { A dummy variable that equals one if the } \\
\text { firm's stock return in the current year is lower } \\
\text { than that in the previous year, and zero } \\
\text { otherwise }\end{array}$ & CRSP \\
\hline IndRet & $\begin{array}{l}\text { A dummy variable that equals one if the } \\
\text { firm's stock return is lower than the industry } \\
\text { median, and zero otherwise }\end{array}$ & CRSP \\
\hline Vega & $\begin{array}{l}\text { Natural logarithm of an option's price } \\
\text { sensitivity to changes in the volatility of the } \\
\text { underlying asset }\end{array}$ & Execucomp \\
\hline Independent Board & $\begin{array}{l}\text { A dummy that equals one if the majority of } \\
\text { board members are classified as independent, } \\
\text { and zero otherwise }\end{array}$ & ISS \\
\hline $\begin{array}{l}\text { Severance } \\
\text { Agreement }\end{array}$ & $\begin{array}{l}\text { A dummy that equals one if a firm has a } \\
\text { contract which ensures executives some } \\
\text { income protection in the event of losing their } \\
\text { positions, and zero otherwise }\end{array}$ & ISS \\
\hline
\end{tabular}

